Nicholai Studies, Vol. I, No. 2 (2021): 267-342.

DOI: https://doi.org/10.46825/nicholaistudies/ns.2021.1.2.267-342

UDC: 271.222(497.11)-722.52-36:929 Николај Велимировић, свети(410)"1914/1918" 323.23(=163.41)(410)"1914/1918"

Received: December $7^{\text {th }}, 2020$. Accepted: May $13^{\text {th }}, 2021$.

\title{
From the Small Serbian Monastery \\ to the London Cathedral: \\ Father Nicholai Velimirovich \\ on a Mission to Great Britain in the First World War
}

\author{
Slavica Popović Filipović \\ Serbian Medical Society, Section for History of Medicine \\ Belgrade, Serbia - The Sunshine Coast, Australia \\ slavica.popo@yahoo.com
}

„Nothing painted by Giotto attains the beauty of the angel

from the Mileševa monastery a Serbian royal foundation."

Arthur Evans, English archaeologist, the president of the Royal Archaeological

Association, one of the founders of the Serbian Relief Fund

\begin{abstract}
The life and work of father Nicholai Velimirovich (1880-1956) is a limitless historical source, which has been encouraging, for the past 100 years, various researches in the Serbian, English, and other languages around the world. Velimirovich, as a person, and his numerous writings can be viewed from different aspects. This article, that is dedicated to father Nicholai Velimirovich, is an attempt to highlight his mission and role in the Great Britain during the First World War. In order to better understand the importance of his mission, we have described the establishment and operation of the Serbian Relief Fund, the Committee of the Serbian Red Cross Society, and the Scottish Women's Hospitals in their medical and humanitarian missions for the Serbian people in the Great War.

Apart from the significant role of father Nicholai Velimirovich, we remember many other great humanists and humanitarians working with and
\end{abstract}


within these various medical and humanitarian missions. With their unforgettable achievements they helped treat people. and to mitigate the terrible suffering of the Serbian people during the great epidemic of typhus in Serbia, and during the great Exodus through the rugged Albanian mountains, during the exile on Corfu, at the Salonica Front, North Africa, Corsica, and France, as well as on the Russian Front, and in Dobruja and even after the Great War. As a representative of the small Serbian nation, father Nicholai Velimirovich held arousing speeches, religious sermons, and wrote numerous literary religious writings, and thereby he confirmed that in the midst of wartime conflagration it is possible for great humane achievements to appear. That is why that impressive spiritual dimension of the mission, which included father Velimirovich and his contemporaries, did not cease to continue to inspire historians, writers and other authors - in the past, present, and the future.

Key words: Nicholai Velimirovich, The Great War, Great Britain, Serbian Relief Fund, Scottish Women's Hospitals.

\title{
Од малог српског манастира до лондонске катедрале:
} Отац Николај Велимировић у мисији у Великој Британији у Првом светском рату

\author{
Славица Поповић Филиповић \\ Секција за историју медицине Српског лекарског друштва \\ Београд, Србија - Саншајн Коуст, Аустралија
}

„Ништа што је насликао Ђото не достиже лепоту анђела из српске краљевске задужбине, манастира Милешева.“ Арйур Еванс, археолої, йреgсеgник Кратевскої археолошкої

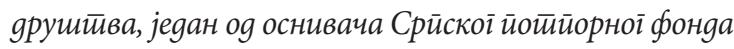

Апстракт: Ово истраживање, посвећено оцу Николају Велимировићу, усредсређено је на његову мисију и улогу у Великој Британији током Првог светског рата. Да бисмо боље разумели значај његове мисије, 
описали смо оснивање и рад Српског фонда за помоћ, Одбора Српског друштва Црвеног крста и болница Шкотске жене у њиховим медицинским и хуманитарним мисијама за српски народ у Великом рату.

Кључне речи: Николај Велимировић, Велики рат, Велика Британија, Српски потпорни фонд, Болнице шкотских жена.

\section{Увод:}

\section{Јеромонах Николај Велимировић у освит Првог светског рата у Нишу}

Почетак Првог светског рата затекао је јеромонаха Николаја Велимировића у манастиру Раковица, одакле га судбина води у Ниш, у ратну престоницу Краљевине Србије. Из Београда у Ниш су прешли Влада и Народна скупштина, чланови страних дипломатских представништава. Према литератури, априла 1915, отац Николај Велимировић је био позван на разговор код Николе Пашића, српског председника владе. Том приликом Никола Пашић је, у име Српске владе, саопштио Велимировићу да га шаље у Енглеску и Америку, на мисију у одбрану српског рода. На питање оца Николаја шта ће тамо радити, уследио је одговор: „Ка'шће ти се само, Никола“.

„У великим историјским тренуцима, судбина додели сваком улогу, и не пита", записао је Милош Црњански. Отуда из мале и напаћене Србије, с вишевековном историјом слободарства, доктор Никола Велимировић, духовног имена јеромонах Николај, напушта манастирске двери и као богоугодни човек и велики српски духовник, полази у значајну мисију, преко Ламанша и Атлантика. Уместо планираних пар месеци, Велимировић је у Великој Британији и Америци провео период од априла 1915. до априла 1919. године. Из Лондона је отишао у Америку, где је боравио од јуна до септембра 1915. године. У Лондону и другим британским градовима, у време Првог светског рата, отац Ни- 
колај Велимировић је заједно са српским дипломатама и бројним интелектуалцима, бранио хришћанска права српског народа. Мада је отац Николај Велимировић више познат по свом духовном животу, овај рад посвећујемо његовом друштвеном, патриотском и хуманитарном раду.

\section{Оснивање Српског потпорног фонда у Лондону, септембра 1914.}

„Врлина је као жеђ, кад човек почне да је пије, све више жедни и све више тражи да је пије. Онај, који почне вежбати врлину милосрђа не зна меру у томе нити признаје икакву меру.“

Николај Велимировић

Оснивање и деловање Српског потпорног фонда је имало велику улогу у медицинској и хуманитарној помоћи Србији у Првом светском рату. Оснивање Српског потпорног фонда (The Serbian Relief Fund), у Лондону, 23. септембра 1914. године, покренули су пријатељи српског народа у Великој Британији. Српски потпорни фонд је деловао под патронством Краљице, за председника је имао почасног епископа Лондона, док је председавајући био господин Бертрам Кристијан, секретар Ситон-Вотсон и благајник сер Едвард Бојл.

Деловање Српског потпорног фонда (даље у тексту СПФ), подржале су угледне личности британског друштва: сер Артур Џон Еванс (Sir Arthur John Evans, 1851-1941), Poберт Вилијам Ситон-Вотсон (Robert William Seton-Watson, 1879-1951), Хенри Викем Стид (Henry Wickham Steed, 18711956), сер Чарлс Вилијам Чедвик Оуман (Sir Charles William Chadwick Oman, 1860-1946), сер Игнациус Валентин Чирол (Sir Ignatius Valentine Chirol, 1852-1929), господин Бертрам Кристијан (Mr. Bertram D. Christian, ?-1953), Дејвид Лојд 
Џорџ (David Lloyd George, 1863-1945), Џорџ Маколи Тривељан (George Macaulay Trevelyan, 1876-1962), леди Констанс Бојл (Lady Constance Jane Knight Boyle, 1855-1944), сер Едвард Бојл (Sir Edward Boyle, the Second Baronet, 18781945), Харолд Темперли (Harold William Vazeille Temperley, 1879-1939), Ноел Едвард Ноел-Бакстон (Noel Edward NoelBuxton, 1869-1948), Волтер Херингтон Кроферд Прајс (Walter Harrington Crawfurd Price, 1881-1967), сер Едмунд Џон Монсон (Sir Edmund John Monson, 1883-1969) и други. Донације у новцу, у санитетској опреми и другим помоћима, стизале су од британског народа и земаља Комонвелта, на адресу СПФ у Лондону (The Serbian Relief Fund Depot, 5 Cromwell Road, London, S.W.)

Велики допринос у упознавању британске јавности са Србијом дали су познати британски историчари, новинари и писци. Међу њима посебно су се истакли Роберт Вилијем Ситон-Вотсон, Хенри Викем Стид и сер Артур Џон Еванс, који су учествовали у оснивању и деловању Српског потпорног фонда. Публициста, Хенри Викем Стид (Henry Wickham Steed, 1871-1956), британски новинар био је познат као дугогодишњи сарадник Тајмса (The Times), уредник часописа The Review of Reviews. Сер Артур Џон Еванс (Sir Arthur John Evans, 1851-1941), признат британски археолог, проналазач критске културе је, као председник Краљевског археолошког друштва посетио Србију, обишао многе српске манастире, дивио се српском историјском и културном наслеђу. Између осталог, записао је:

„Ништа што је насликао Ђото не достиже лепоту анђела из српске краљевске задужбине, манастира Милешева.“

[„Nothing painted by Giotto attains the beauty of the angel from the Mileševa monastery a Serbian royal foundation."]

Шкотланђанин, Роберт Вилијем Ситон-Вотсон (Robert William Seton-Watson, 1879-1951), новинар, публициста и 
велики путник је, обишавши многе европске земље, стекао посебно интересовање за словенске народе. Своја интересовања и боље познавање Словена проширио је у „Школи за словенске студије“ (The School of Slavonic Studies), учествовао у њеном оснивању, био један од уредника Словенско $\bar{\imath}$ йреілеga (The Slavonic Review) и Нове Евройe (New Europe). Како је Ситон-Вотсон био одушевљен победама српске војске у балканским ратовима, посетио је Србију на почетку Првог светског рата, заједно са Џорџом Тревељаном (George Macaulay Trevelyan, 1876-1962), познатим британским историчаром. Том приликом, Ситон-Вотсон и Тревељан су се срели с премијером Николом Пашићем и другим српским политичарима и познатим личностима. Ситон-Вотсон је заволео Србију, по његовим речима „то је земља без разметања и парадирања“. За њега српски џентлмен је био српски сељак, коме се посебно дивио и истицао његову храброст у извојевању слободе. ${ }^{1}$ Истовремено, Ситон-Вотсон скреће пажњу на велики број инспиративних ратних сведочанства из Србије, објављених из пера британских писаца, новинара и чланова медицинских мисија, који су били најверодостојнији вид промоције српске борбе за ослобођење.

Ситон-Вотсон је истакао велику улогу православног свештенства у неговању и очувању вишевековне српске традиције. Као доказ да је познавао добро епску поезију, важног чиниоца у српској култури, Ситон-Вотсон је српског јунака Краљевића Марка упоредио с Робином Худом, енглеским јунаком и Робертом Брусом (Robert Bruce, 12741329), шкотским националним јунаком. Све ово допринело је да Ситон-Вотсон остави бројна писана сведочанства о Србији, а нека од њих су: Духовноси Србије (The Spirit of the Serb (London: Nisbet \& Company Limited, 1915)),

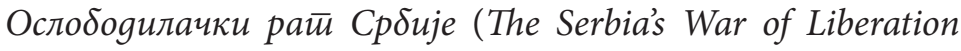

\footnotetext{
${ }^{1}$ R.W. Seton-Watson, “The Spirit of the Serb,” y Nataša Petković, Britanci o Srbiji 1900. do 1920., Biblioteka „Dissertatio“/ Zadužbina Andrejević, 5 (Beograd: Zadužbina Andrejević, 1996), 30-34.
} 
(London: Serbian Relief Fund, 1915)), Балкан, Ийалија и Jagранско море (The Balkans, Italy and the Adriatic (London: Nisbet \& Company Limited, 1915)) и Cрбија јуче, gанас и cyūpa (Serbia Yesterday, Today and Tomorrow (Westminster: Kossovo Day Committee, 1916)). ${ }^{2}$

Као што смо већ поменули, Ситон-Вотсон је обилазио Србију крајем 1914. и почетком 1915, како би видео шта је потребно српском народу и како му најбоље помоћи. Отуда и Вотсоново велико залагање да подржи рад Српског потпорног фонда, као једне независне хуманитарне организације намењене за помоћ српском народу у ратним страдањима.

Већа сазнања и боље познавање Србије и српског народа у широј британској јавности нису дошла само преко бројних британских историчара, публициста и новинара. У афирмацији и кампањи за српски народ у промоцији српске културе, поред поменутих британских историчара, политичара, новинара и писаца имали су српски интелектуалци у Лондону. У научној и културној модернизацији српског друштва на међународном нивоу велики допринос дали су: Јован Цвијић (1856-1927), географ, професор Велике школе, Богдан Поповић (1863-1944), професор и писац, Матија Бошковић (1864-1950), краљевски српски посланик у Британији, Славко Грујић (1871-1937), српски дипломата, Павле Поповић (1868-1939), књижевни историчар и професор, Гргур Јакшић (1871-1955), дугогодишњи краљевски српски посланик у Паризу, Михаило Гавриловић (1868-1924), историчар, дипломата и архивиста, Војислав М. Јовановић (1884-1968), књижевни историчар, др Тихомир Ђорђевић (1868-1944), историчар и етнолог, др Милан Ђурчин (1880-1960), књижевник, песник, преводилац и публициста, Чедомиљ Мијатовић (1842-1932), историчар, политичар, дипломата, писац и други. Међу виђеним Србима у Лондону, отац Николај Велимировић

\footnotetext{
2 Petković, Britanci o Srbiji 19oo. do 1920., 29-37.
} 
је за блиске сараднике имао Чедомиља Мијатовића, дугогодишњег српског посланика, који је живео у Лондону, од 1889. године. Други је био Србин из Херцеговине, Димитрије Митриновић (1887-1953), песник, критичар и филозоф, човек велике енергије и недостижних визија, интелектуалац у седишту политичких и културних прилика у британском, али и ширем европском друштву.

Оснивање и деловање Српског потпорног фонда је посебно имало подршку неколико жена, које су захваљујући својој животној судбини имале прилику да боље упознају Србију и разумеју традицију и обичаје српског народа. Биле су то: госпођа Елизабет Беси Христић (Madam Elisabeth O’Brien Christitch (1861-1933), ${ }^{3}$ сифражеткиња и писац, срп-

\footnotetext{
${ }^{3}$ Елизабет О’Брајен Христић (Madame Elisabeth Bessie O’Brian), Иркиња, писац и сифражеткиња, рођена је у покрајини Лимерик, у Северној Ирској (Bruff, the Northern Ireland). Као писац оглашавала се књижевним прилозима под псеудонимом Бен Хурст. Удајом за љубомира Христића (1856-1930), српског официра, сина Николе Христића, живела је у Београду, где је родила сина Николу и ћерке Ани и Џени. У Београду, заједно са српским женама, покреће оснивање Српског народног савеза (1906), који је објединио деловање свих српских женских друштава и убрзо постао чланица Међународног савеза жена (The International Council of Women). У балканским ратовима Елизабет Христић је, заједно са ћеркама, радила као добровољна болничарка у једној београдској резервној болници. На самом почетку Првог светског рата, госпођа Христић је у Лондону била међу првима, која се залагала да се помогне Србији, па тако се њен женски апел чуо у разним дописима, објављеним у угледним британским новинама. Српска химна, у преводу Елизабет Христић, објављена у Тајмсу, а поводом обележавање Видовдана 1916, умножена је у хиљаде примерака и продавала се као помоћ за Србију. Госпођа Христић је била међу иницијаторима у оснивању Српског потпорног фонда у Лондону (септембра 1914). У саставу СПФ, а и индивидуално, заједно с ћерком Ани залаже се за помоћ српском народу у време кад су многи прекинули дипломатске односе са Србијом. Елизабет и Ани, оснивају медицинску „Мисију Христић“, која је заједно с магацином санитетског материјала деловала у Ваљеву 1915. године. Доласком великог повлачења, Елизабет и Ани одбијају да напусте болницу, па тако су једно време радиле у Ваљеву, Трстенику, потом у Београду, где у време окупације оснивају народну кухињу. Опширније: Slavica Popović Filipović, Hrabrost između redova: Ani Hristić u Srbiji i vreme odvažnih / Courage Between the Lines: Miss Annie Christitch in Serbia and the Time of the Brave (Beograd: Društvo istoričara Srbije — „Stojan Novaković“, 2015), 290-332.
} 
ска снаха с ћерком Ани Христић (Miss Annie Christitch, 18851977), новинарка, дописница Daily Express-a, Мабел Данлоп Грујић (Mabel Dunlap Gordon Grouitch, 1881-1956), супруга Славка Грујића, тадашњег секретара Министарства спољних послова, кнегиња Дарија Прат (Daria Pankhurst Wright Pratt, Karageorgevich, 1859-1938), супруга кнеза Алексе Карађорђевића (Prince Alexis Karageogevitch, 1859-1920), праунука вожда Карађорђа Петровића, леди Пеџет (Lady Paget, 1881-1958), супруга сер Ралф Пеџета, британског амбасадора у Србији (1910-1912), леди Вајтхед (Lady Marian Whitehead, 1869-1932), која је боравила у Београду, као супруга Џејмса Вајтхеда (Sir James Whitehead), британског посланика у Србији 1906-1910. године. У прилог томе др Ситон-Вотсон сведочи: „Заслужује да се каже да је она (госпођа Елизабет Христић) била прва особа у Британији, која се јавно залагала у корист Србије након избијања рата.“"

Априла 1915. године, овој британско-српској елити у Лондону, придружује се јеромонах Николај Велимировић, духовник, који је, обилазећи британске градове, држао ватрене говоре окупљеном народу, па тако ширио своју хришћанску мисију. Јеромонах Николај Велимировић је у Британији објавио један број говора, који данас најбоље сведоче о ширењу његове хришћанске и хуманитарне мисије у време Првог светског рата. Велимировић је, уз подршку и помоћ Српског посланства у Лондону, објавио дванаестак брошура и памфлета, а неке од њих су биле насловљене: Релиіија и националности у Србији (Religion and Nationality in Serbia,

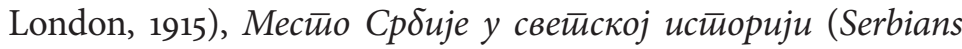
Place in Human History, London, 1915), Релиіиозни gух Словена (The Religious Spirit of the Slavs, London, 1916), Нови иgеал $y$ образовану (The New Ideal in Education, London, 1916), Cрбија у светилостии и мраку (Serbia in Light and Darkness, London, 1916), Душа Србије (The Soul of Serbia, London, 1917), Аїонија

\footnotetext{
${ }^{4}$ R. V. Seton-Watson, "Orbituary Mme. Elizabeth Christitch," The Times (London, February 2, 1933): 15.
} 
Цркве (The Agony of the Church, London, 1917), Хришћанстиво и

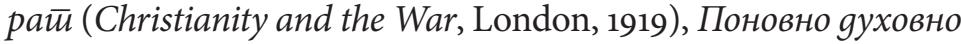
рађанье Евройe (The Spiritual Rebirth of Europe, London, 1920). Треба напоменути да су Велимировићеви говори и беседе одржане на угледним универзитетима и црквама, а издања су имала предговоре и приказе познатих британских историчара и црквених великодостојника.

\section{Прослава Видовдана 28. јуна 1916,}

\section{у Лондону и широм Велике Британије}

После великог егзодуса српске војске крајем 1915, српски народ није био у могућности да у егзилу прославља Видовдан - један од највећих српских празника. Маја 1916, на предлог једног броја Срба у избеглиштву, у Лондону је донета одлука да се обележи Видовдан у целој Великој Британији. Комитет за прославу и обележавање Видовдана је формиран на иницијативу др Елси Инглис, оснивача и руководиоца Болнице шкотских жена, које су деловале у Србији и пратиле Србе на свим фронтовима.

За прославу Видовдана, који се обележавао као Дан Косова, у Лондону 1916, основан је Национални комитет (The Kossovo Day Committee, 8o Parliament Street, London, S.W.), под председништвом др Елси Инглис (Chairman - Dr Elsie Inglis), а у саставу: новинар Роберт Вилијем Ситон-Вотсон (Mr. Robert William Seton-Watson), леди Елионор Гроган (Lady Ellionor Grogan), госпођа Гертруда Карингтон Вајлд (Mrs. Gertrude Carrington-Wilde) $)^{5}$ и финансијски секретар

\footnotetext{
${ }^{5}$ Госпођа Гертруда Карингтон Вајлд (Mrs. Gertrude Carrington Wild, 18561945), Иркиња, велики хуманиста и борац за женска права, била је ћерка Артур Веида (Arthur Wade), капетана у Шкотској војсци, а супруга господина Алфреда Карингтона Вајлда (Mr. Alfred Carrington Wild). Госпођа Гертруда Вајлд је била чланица Српског потпорног фонда у Лондону, од оснивања до краја деловања фонда (1914-1921). Дала је велики допринос у свим сегмен-
} 
Ф. С. Линдо (Mr. F. C. Lindo), сви чланови Српског потпорног фонда од самог оснивања. ${ }^{6}$ Видовдан, највећи српски празник је прослављен први пут у Британији 1916, али се обележавао и наредне две године, све до краја рата.

У Комитету за прославу Видовдана у Лондону, српски народ је имао своје изасланике: били су то јеромонах Николај Велимировић, потоњи епископ жички и охридски и др Милан Ћурчин (1880-1960), књижевник, публициста и преводилац, тада високи службеник српског посланства у Лондону. Николај Велимировић је учествовао у организовању Видовдана, на посебан позив, који је стигао од Кентеберијског надбискупа (at the invitation of the Archbishop of Canterbury).

Међу првима Комитет за обележавање Видовдана добио је подршку чланица Болнице шкотских жена: леди Ани Пирсон Каудри (Lady Annie Pearson Cowdray, 1860-1932), ${ }^{7}$ пред-

тима СПФ, а посебно као председница Образовног комитета СПФ, који је имао задатак да организује школовање српске омладине у избеглиштву у Великој Британији, у време Првог светског рата. У послератном периоду, била је покретач и велики задужбинар оснивања Дома за ратну сирочад у Нишу, који је често посећивала. Носилац је Ордена Светог Саве II реда, а захвалан српски народ је госпођи Вајлд у Нишу подигао споменик испред Енглеско-

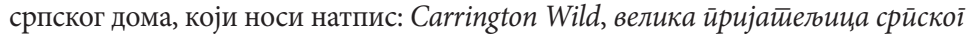
нароga. У знак великог човекољубља за добробит српског народа, Чедомиљ Мијатовић јој је посветио дело: Усйомене јеgної балканскоі gийломайе - То Gertrude Florence Wild in Gratitude for her Friendship (уп. Chedomille Mijatovich, The Memoirs of a Balkan Diplomatist (London: Cassell and Company, 1917), [vi]).

${ }^{6}$ Jennifer Blake, “Kossovo Day 28 June 1916," Britić - The British Serb Magazine (London, March 12, 2016).

7 Леди Каудри (Lady Annie Pearson Cowdray, 1860-1932) и виконт Витман Дикинсон Пиарсон Каудри (Lord Weetman Dickinson Pearson Cowdray, 1856 1927), индустријалац, либерални политичар, били су велики шкотски филантропи, а како су живели на породичном имању Данхет, допринели су општем напретку града Абердина. Леди Каудри, активна сифражеткиња, била је чланица Лондонског комитета Болнице шкотских жена, па тако је помогла оснивање и деловање болнице у Србији и за Србе у избеглиштву, на свим фронтовима. Поред ангажовања у Комитету, леди Каудри је лично послала 200 постеља и велику количину санитетског материјала за Болницу шкотских жена у Острову, која је имала пресудну улогу у санирању рањеника после битке за Кајмакчалан. Као чланица СПФ, леди Каудри је подржала многе акције за Србе, посебно се ангажовала у школовању српске деце у Единб- 
седнице Лондонског комитета Болнице шкотских жена (The London Committee of the Scottish Women's Hospitals), rocпође Гертруде Кинел (Mrs. Gertrude Kinnell), чланице Шкотских жена и госпође Хилде Мери Изабел Петри (Mrs. Hilda Mary Isabel Petrie, 1871-1957), Иркиње, британског египтолога, а супруге и сарадника Флиндерс Петрија (Flinders Petrie, 1853-1942), родоначелника научне археологије. Госпођа Петри је, као почасни секретар Комитета Болнице шкотских жена, посетила Србију, а у знак њених великих заслуга одликована је Орденом Светог Саве.

У пролеће 1916. године, велики број чланова британских медицинских и хуманитарних мисија из Србије се вратио у домовину, па с тако свежим сећањима и искуством, радо прихватају да дају свој допринос. Тако су у раду Комитета учествовале чланице Болнице шкотских жена из Србије, које су се вратиле после великог повлачења или репатријације преко Швајцарске. Међу њима посебно место заузима др Елси Мод Инглис (Dr. Elsie Maud Inglis, 1864-1917), лекарка и сифражеткиња, оснивач и руководилац Болнице шкотских жена, која је од четрнаест формираних јединица, десет наменила Србима. Др Елси Инглис је дошла у Србију у пратњи шкотске баронесе Евелине Хаверфилд (Honourable Evelina Haverfield, 1867-1920), која је као чланица Болнице шкотских жена радила у Крагујевцу, Младеновцу, Лазаревцу и Крушевцу, а касније, као руководилац Транспортне јединице, пратила др Елси Инглис, руководиоца Болнице шкотских жена на Руском фронту и Добруџи.

ургу и Глазгову, а преко распуста примала децу на породично имање. По ослобођењу, дошла је у Београд и у име Лондонског и Единбуршког комитета Болнице шкотских жена, предала велику донацију, као помоћ у оснивању Меморијалне болнице др Елси Инглис, на Дедињу. Како је била велики доброчинитељ нудиљске школе у Абердину, пренела је своје искуство и подршку у формирању прве Школе за нудиље у Београду. Захваљујући леди Каудри урађена је биста др Елси Инглис, рад вајара Ивана Мештровића, која је данас изложена у Националној галерији Шкотске. Леди Кауди је одликована Орденом Светог Саве, I реда, а једна улица у Београду је некада носила њено име. Опширније: Popović Filipović, Hrabrost između redova, 36o-364. 


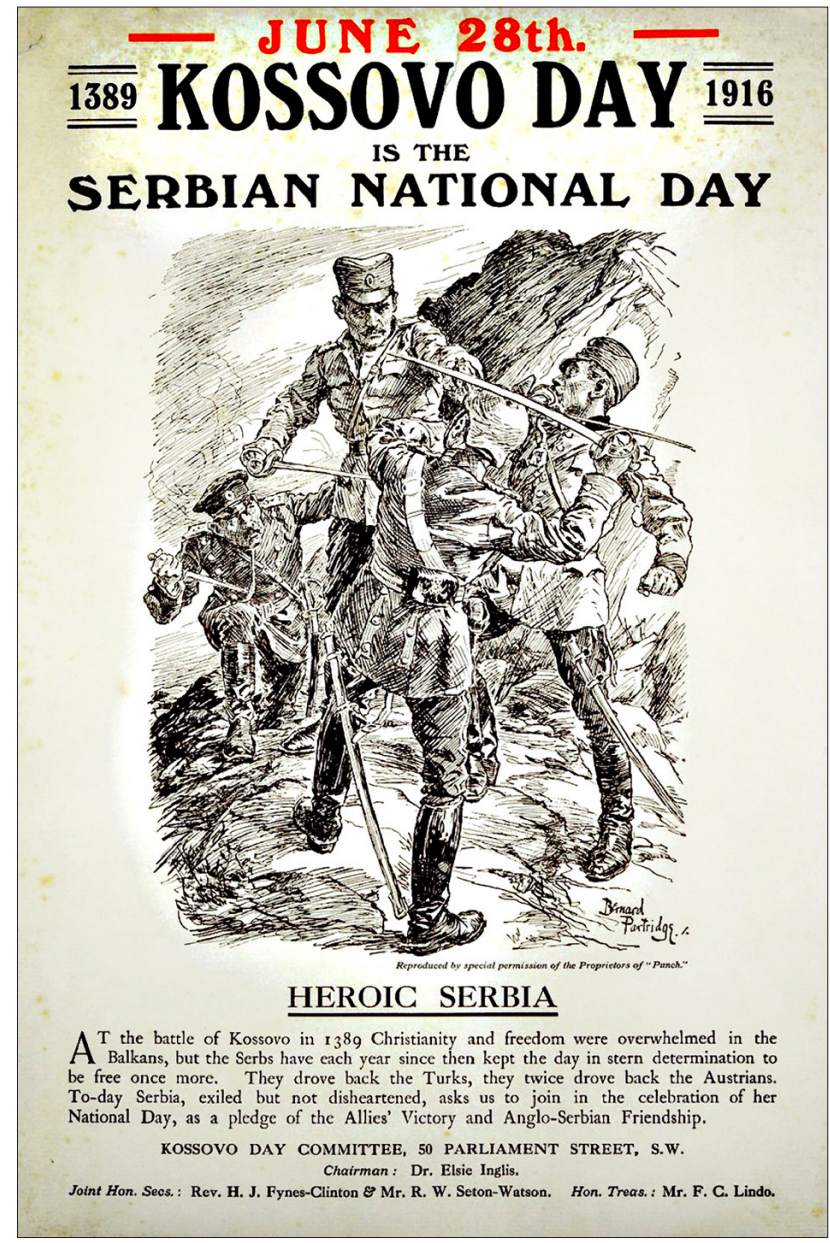

Fig. 1. WWI poster - Kosovo Day is the Serbian National Day: June 28th. 1389-1916. Сл. 1. Плакат који приказује борбу српског војника против аустро-угарског, немачког и бугарског војника, објављен 1916. године поводом обележавања Видовдана у Лондону (извор: https://velikirat.nb.rs/)

Један од угледних чланова Комитета био је сер др Џејмс Бери (Sir Dr. James Berry, 1860-1946), дугогодишњи лекар лондонске Краљевске бесплатне болнице (The Royal 
Free Hospital, London). Др Бери је боравио у Србији, 1915. као руководилац Енглеско-српске болнице, која је уз финансијску помоћ Српског потпорног фонда, деловала у Врњачкој Бањи. Медицинску мисију у Србији поделио је са супругом др Френсис Меј Дикинсон, леди Бери (Dr. Franses May Dickinson Lady Berry, 1857-1934), с којом ће у Лондону, у послератном периоду основати фонд за специјализацију југословенских лекарки. Уважено британско свештенство је у Комитету имало свог представника - био је то свештеник Хенри Клинтон (Rev. Henry Joy FynesClinton, 1875-1959), који је

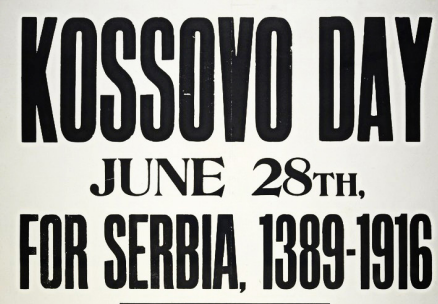

ADVANCE COPIES OF WISS E BIIVES DAIES' BODI' " MAY BE BOOKED HERE

\section{PRICE 6/: NET.}

ALL PROFITS TO BE CIVEN TO THE SERBIA FUND.

Fig. 2. WWI poster - Kosovo Day, June $28^{\text {th }}, 1916$.

Сл. 2. Дан Косова - Видовдан 1916, плакат Српског потпорног фонда (извор: https://velikirat.nb.rs/) заступао Англиканско-источно црквено удружење (the Anglican-Eastern Churches Association).

Запажени су говори чланова медицинских мисија, који су желели да са својим земљацима поделе лична искуства и доживљаје у Србији: др Елси Инглис је одржала говор у Хемпстеду (Hampstead) и другим местима, баронеса Евелина Хаверфилд се обратила народу у Ледерхеду (Leatherhead, Surrey), госпођа Мабел Стобарт је говорила у Лимингтону (Lymington), др Џејмс Бери у Линколну (Lincoln), др Франсис Меј Дикинсон Бери у Ајлезбурију (Aylesbury). Инспиративан говор у Лидцу (Leeds) одржала је госпођа Елен Дејвис Чиверс (Mrs. Ellen Davies Chivers, 1888-1939), медицинска сестра из Пете јединице СПФ (Друге јединице британских фармера), 
у Пожаревцу, а аутор књиге Фармер у Србији (Ellen Davies Chivers, A Farmer in Serbia (London: Methuen, 1916)).

Свечаностима у Бирмингему су, поред др Томаса Гвин Меитленда (Dr. Thomas Gwynne Maitland), ${ }^{8}$ из Бирмингемског медицинског института, присуствовале леди Пеџет и Делфа Иванић, ${ }^{9}$ чланица Кола српских сестара, која је о томе писала у својим Усйоменама. Др Томас Меитленд, лекар у болници леди Пеџет у Србији, а стари познаник Делфе Иванић из Скопља, одржао је запажен говор у Волсолу (Walsall, недалеко од Бирмингема). Делфа Иванић, др Милан Милојевић и његова супруга Мица Васић су топло примљени у Бирмин-

\footnotetext{
8 Др Томас Меитленд (Dr. Thomas G. Maitland, 1895-1948), дипломирао је медицину у Единбургу (1907), докторирао (1908), стекао титулу доктора филозофије на Универзитету у Манчестеру, био уредник листа The Manchester Medical School Gazette, предавач на Универзитету у Велсу и лекар Бирмингемског медицинског института (The Birmingham Medical Institute), направио велики напредак у области британске хирургије и ортопедије. У Скопљу, у саставу Прве јединице СПФ дао је велики допринос у оснивању и деловању VI резервне болнице за оболеле од трбушног, повратног и пегавог тифуса. По повратку у домовину, својим дописима у медицинским часописима апеловао је да се помогну Срби, учествовао у организовању Видовдана, школовању српске деце у Бирмингему и других доброчинства за Србију (уп. Slavica Popović Filipović, Iz postojbine javora: kanadsko-britanska medicinska $i$ humanitarna pomoć Srbiji u Prvom svetskom ratu / From the Homeland of Maple Tree: the Canadian-British Medical and Humanitarian Help to Serbia in the First World War (Beograd: Srpsko lekarsko društvo, 2013), 207-225).
}

9 Делфа Иванић (1881-1972), наставница француског језика, преводилац, писац и хуманиста, заједно са Надеждом Петровић покренула је оснивање Кола српских сестара (1903), коме остаје верна до краја, као секретар, потпредседница и председница друштва. У Првом балканском рату с Љубицом Луковић је основала IV резервну болницу у Београду. У Првом светском рату у Скопљу, помаже деловање Прве јединице СПФ, на челу с леди Пеџет. После егзодуса, са супругом Иваном Иванићем у избеглиштву, покренула је многе хуманитарне акције за добробит српског народа у Италији и Француској. У Великој Британији је учествовала у организацији Видовдана, а као блиска сарадница Гертруде Карингтон Вајлд, допринела је да се један број српске избегле деце прими на школовање у британске школе. Делфа Иванић је била потпредседница Српског народног женског савеза Краљевине Србије и председница Народног женског савеза Краљевине Југославије, а међу првим женама, одликована Медаљом за милосрђе „Флоренс Најтингејл“. 
гему, који је преко Српског потпорног фонда, међу првима прихватио српску избеглу децу. У Бирмингему, на срдачном скупу грађанства, говориле су леди Пеџет, Делфа Иванић, професор Богдан Поповић и Војислав Антонијевић, ${ }^{10}$ први секретар Српског посланства у Лондону. ${ }^{11}$

У мисији промоције српске историје непроценљив допринос дао је јеромонах, касније Владика Николај Велимировић, својим предавањима и публикацијама, делима Местио Србије у светиској истиорији, Косово и Вияовgан, итд. Велико интересовање за Србију и српски народ подстакао је својим делима историчар Роберт Вилијам Ситон-Вотсон, покретач и председник Српског потпорног фонда, а аутор неколико наслова о српској прошлости, садашњости и будућности.

Комитет за организацију Дана Косова је објавио извештај о прослави Видовдана у Великој Британији, 1916. године. Извештај је публикован у 85.0оо примерака, док је памфлет Сетон Вотсона изашао у 25.0о0, односно 50.000 примерака. Промоција Дана Косова је добила значај националног догађаја преко бројних прилога и чланака о српској историји, објављених у познатим британским новинама и часописима - The Times, The Daily Mirror, The Globe, The Daily Chronicle. Филмови о Србији су приказани у преко 1.000 биоскопа, захваљујући Pathe Freres и позоришним везама Евелине Хаверфилд и Вере Холм (Miss Vera Holme, 1881-1969), чланицама Болнице шкотских жена у Србији, на Руском фронту и Добруџи, а у послератном периоду у Бајиној Башти.

\footnotetext{
${ }^{10}$ Војислав Антонијевић (1874-1946), српски новинар и дипломата, дипломирао је на Филозофском факултету у Београду. Као дипломата радио је у посланствима Краљевине Србије у Лондону, Бечу, Риму и Мадриду. У време Првог светског рата био је први секретар Српског посланства у Лондону, па тако је учествовао у обележавању Видовдана и других манифестација у промоцији Србије. По дипломатској служби у Вашингтону, вратио се у Београд, где је био постављен за начелника одељења Министарства иностраних послова.

11 Делфа Иванић, Усйомене. Приредила Јасмина Милановић, Библиотека „Посебна издања“ (Београд: Институт за савремену историју, 2012).
} 
Лондонски The Times је објавио целокупан програм свечаности поводом обележавања Видовдана, 28. јуна 1916. године. За ову прилику одштампано је на хиљаде примерака песме 'О Косовском боју', у преводу Елодије Мијатовић (Madam Elodie Lawton Miyatovich, 1825-1908), аутора збирке српске епске поезије, а супруге Чедомиља Мијатовића (1842-1932), српског политичара и дипломате у Лондону. Српска национална химна у преводу госпође Елизабет Христић, извођена је у Лондону, у Катедрали Св. Павла и многим другим храмовима широм земље. Клод Аскју (Mr. Claude Askew, 1865-1917), познат енглески писац, за прославу Видовдана је написао песму „Косово“, у преводу Милутина Бојића.

Међу историчарима био је запажен памфлет др Ситон-Вотсона, под називом Србија: јуче, gанас u cyūpa (Serbia: Yesterday, Today and Tomorrow), који је доживео више из-

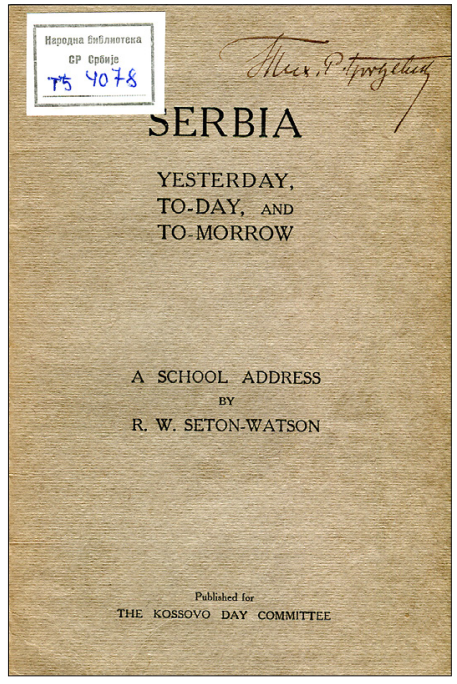

Fig. 3. R.W. Seton-Watson, Serbia: Yesterday, Today and Tomorrow, 1916. Сл. 3. Р. В. Ситон-Вотсон, Србија: јуче, gанас и суӣра, 1916. (извор: https://velikirat.nb.rs/) дања. У плејади познатих аутора, била је историчарка Фени C. Копленд (Fanny S. Copeland), ${ }^{12}$ која је одржала предавање,

\footnotetext{
12 Фени Копленд (Miss Fanny S. Copeland, 1872-1970), историчарка, лингвиста и полиглота, била је аутор бројних текстова о српској историји и литератури, објављених у време балканских и Првог светског рата. Као добар познавалац српске историје, истиче вредност епске поезије, а народне песме сматра „светињом над светињама“. Фени Копленд је рођена у Ирској, школовала се и део живота провела у Единбургу и Лондону, а преко бо година живела у Словенији, где је преминула и почива. Историчарка Копленд се, као добар познавалац српске историје, међу првима огласила о непријатељским злочинима у Србији, заједно с Арчибалдом Рајсом (уп. Archibald Reiss, Report upon the Atrocities committed by the Austro-Hungarian Army during the First Invasion in Serbia, English
} 
и касније га објавила под насловом Жене Србије (The Women of Serbia), ${ }^{13}$ с предговором леди Лејле Пеџет. Позната британска историчарка, ирског порекла, Фени Копленд се међу првима, заједно с Арчибалдом Рајсом (Archibald Reiss, 1875-1929), огласила поводом великих злочина аустроугарске војске у току прве инвазије у Србији.

Један од видова промоције српске историје и културе била је и изложба посвећена Србији (The Serbian Exhibition), одржана у Лондону 1916. године. Госпођа Карингтон Вајлд и Комитет Српског потпорног фонда су организовали изложбу с експонатима домаће радиности „симбола српске националности“, које су заједно с великом

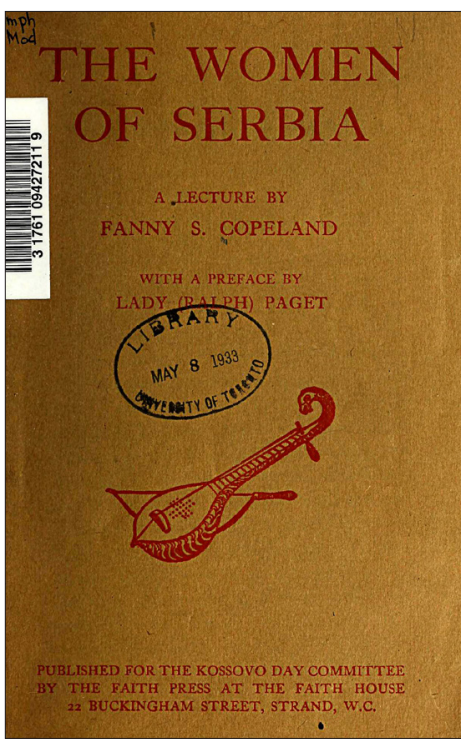

Fig. 4. F. S. Copeland, The Women of Serbia, 1916.

Сл. 4. Ф. Копленд, Жене Србије, 1916. (извор: https://archive.org/) количином топле одеће, направиле српске жене, избеглице на Корзици. На отварању изложбе, поред српских представника, говорили су господин Ситон-Вотсон и госпођа Гертруда Карингтон Вајлд. ${ }^{4}$ О искуствима у Србији, уметница Кора Гордон (Cora Gordon, 1879-1950), писац, и Жан Гордон (Jan Gordon, 1882-1944), новинар, сликар и критичар су написали серију чланака и објавили књигу Срећан

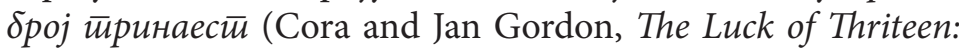

translation by Fanny S. Copeland (London: Simpkin, Marshall, Hamilton, Kent \& Co. Ltd, 1916)).

${ }^{13}$ Fanny S. Copeland, The Women of Serbia, with a preface by Lady (Ralph) Paget (London: The Faith Press for the Kossovo Day Committee, 1916).

14 "Serbian Exhibition," Federal Magazine and the All-Red Mail, 77 (AprilMay 1916): 872. 
Wonderings and Flight through Montenegro and Serbia (New York: E. P. Dutton and Company, 1916)). У оквиру Видовдана, Гордонови су организовали изложбу у Лондону (Walker's galleries, 118, New Bond Street, London: Exhibition of Sketches of Serbia by Mrs. Cora Gordon and Mr. Jan Gordon).

Промоцију српске историје и културног наслеђа подржао је и часопис Ново Доба (New Age), који је за сарадника имао Димитрија Митриновића, ${ }^{15}$ српског песника, филозофа и преводиоца из Херцеговине. Касније часопис Ново Доба прераста у часопис Нова Евройа (New Europe), који излази у Лондону, од 16 . октобра 1916 - 28. октобра 1920. Димитрије Митриновић је међу оснивачима групе Нова Евройа и часописа истог имена Нова Евройа. Тако ће у уредништву једног познатог часописа, Димитрије Митриновић бити у групи угледних британских историчара, књижевника и новинара у пресудним годинама Великог рата.

Бројне свечаности су одржане у градовима од југа до севера Велике Британије, док је централно обележавање Ви-

15 Димитрије Митриновић (1887-1953), истакнути српски песник, филозоф, преводилац, авангардни српски интелектуалац, живео је у Британији, од 1914-1953, па тако годинама био у жижи догађања у Лондону. Димитрије Митриновић је међу оснивачима групе Нова Евройа и часописа истог имена Нова Евройа. Митриновић је рођен у учитељској породици у селу Доња Поплат у Херцеговини. После завршене гимназије у Мостару, студирао је филозофију, психологију и логику у Загребу, Београду, наставио студије у Бечу и Минхену, а апсолвирао у Тибингену 1914. Његова прва песма изашла је у Новој Искри, а следило је публиковање великог броја песама у часописима Босанска вила, Бранково коло, Дело, Нова искра, Срђ, Срйски книжевни іласник, Словенски јуі, Варgар, Зора, Хрвайски Ђак, Оgјек и Савременик. Митриновић је творац многих футуристичких праваца у књижевности, па отуда се убраја у ауторе модерне савремене српске и југословенске књижевности. Говорио је грчки и италијански, а своја дела писао на енглеском и немачком, преводио са сва четири страна језика. Као филозоф био је зачетник идеје да се преко уједињења културе дође до политичких идеја Уједињене Европе, па отуда многа његова начела су и данас важећа за Европску унију. По карактеру и делу, био је оригиналан, храбар, јединствен и футуриста, чија се предвиђања данас остварују. Димитрије Митриновић је био близак пријатељ оца Николаја Велимировића, па је у много чему утицао на његове идеје и ставове. 
довдана било у Лондону. Свечано обележавање Видовдана се проширило од једног дана на целу недељу. Посланик Краљевине Србије у Лондону, господин Матеја Бошковић, говорио је у једном клубу испред бројних високих званица политичког и дипломатског кора.

Духовни печат централној свечаности у Лондону дао је отац Николај Велимировић, који је на позив кентерберијског бискупа, одржао говор у Катедрали Св. Павла. У дугој црквеној историји, направљен је преседан како би српски свештеник служио и проповедао у једној англиканској цркви. На служби хор српске деце, која су се школовала у Британији, певао је српску химну. Отац Николај Велимировић је одржао беседу на свечаној литургији, у присуству британског премијера Аскуита (Н. Н. Asquith), министра иностраних дела, сер Едварда Греја (Sir Edward Grey), високих званица британске војске, владе и дипломатије, породица преминулих лекара и сестара у Србији, представника Британског Црвеног крста и српске интелектуалне елите у Британији. У лондонској катедрали, коју је посетило хиљаде верника, отац Николај Велимировић, свештеник мале и расељене нације, држао је беседу, коју је насловио Душа Србије.

\section{Говор јеромонаха Николаја Велимировића у Катедрали Св. Павла}

Прослава Видовдана у Лондону, године 1916.

\section{Душа Србије}

„Дошао сам из Србије, из европске поноћи. Тамо нигде ни зрачка светлости. Сва светлост побегла са земље на небо и једино нам одозго светли. Па ипак, ми нејаки у свему, сада овако, јаки смо у нади и вери, у скоро свануће дана. Захвалан сам лорду Архиепископу кентеберијском, који ми је 
омогућио да на свети Видовдан, овог лета Господњег 1916. године, у овој прекрасној цркви Светог Павла, пред његовим Височанством Џорџем Петим и најугледнијим Енглезима могу да вам се обратим.

Господо и пријатељи! Цео дан јуче провео сам разгледајући овај величанствени храм, који је понос Енглеске и хришћанства. Ја сам видео да је он саграђен од најскупоценијег материјала, донесеног из разних крајева империје у којој сунце не залази. Видео сам да је саграђен од гранита и мермера, које су испирали таласи стотине мора и океана, и да је украшен златом и драгим камењем, донетим из најскупоценијих рудника Европе и Азије, и уверио сам се да се овај храм с правом убраја у једно од архитектонских чуда света.

Но, господо и пријатељи! Ја долазим из једне мале земље на Балкану у којој има један храм, и већи, и лепши, и вреднији, и светији од овог храма. Тај храм се налази у српском граду Нишу и зове се Ћеле Кула. Тај храм је сазидан од лобања и костију мог народа. Народа, који пет векова стоји као стамена брана азијском мору, на јужној капији Европе. А кад би све лобање и кости биле узидане, могао би се подићи храм триста метара висок, толико широк и дугачак, и сваки Србин би данас, могао подићи руку и показати. Ово је глава мога деде, мога оца, мога брата, мога комшије, мога пријатеља, кума!

Пет векова Србија лобањама и костима својим брани Европу да би она живела срећно. Ми смо тупили нашим костима турске сабље и обарали дивље хорде, које су срљале као планински вихор на Европу, и то, не за једну деценију, нити за једно столеће, него за сва она столећа, која леже између Рафаела и Ширера. За сва она бела и црвена столећа у којима је Европа вршила реформацију вере, реформацију науке, реформацију политике, реформацију рада, реформацију целокупног живота. Речју, када је Европа вршила 
смело кориговање, и богова, и људи из прошлости, и када је пролазила кроз једно чистилиште, телесно и духовно.

Ми смо, као стрпљиви робови, ми смо се клали са непријатељима њеним, бранећи улаз у то чистилиште, и другом речју, док је Европа постојала Европа, ми смо били ограда њена, жива и непробојна ограда, дивље трње око питоме руже. На Видовдан 1389. године српски кнез Лазар, са својом храбром војском, стао је на Косову Пољу као браник хришћанске Европе, и дао живот за одбрану хришћанске културе. У то време Срба је било колико и вас Енглеза. Данас их је десет пута мање. Где су? Изгинули бранећи Европу. Сада је време да Европа Сpбији врати тај дуг. “16

\section{Fr. Nicholai Velimirovich}

\section{addressed a congregation gathered}

\section{at St. Paul's Cathedral in London, on June $28^{\text {th }}, 1916$}

"Gentlemen and friends,

I am coming from Serbia, from European midnight. There is no ray of light, not a single trace. All the light went from the ground to the sky and the sky is the only place where the light is coming from. Nevertheless, we that are weak in everything but are strong in faith and hope that dawn will soon arrive. I am grateful to Lord Archbishop, Randall Cantuar, that allowed me, on this holy day, Vidovdan, year of Our Lord 1916, in this

\footnotetext{
16 Orthodoxy Cognate Page, "Vidovdan Address of Saint Nikolai Velimirovich and Saint Lazar the Great Martyr of Kossovo," OCP Pan-Orthodox Media Network, https://theorthodoxchurch.info/blog/news/vidovdan-address-of-saintnikolaj-velimirovic-and-saint-lazar-the-great-martyr-of-kosovo/, posted on July 1, 2019, seen on February 21, 2020.
} 
beautiful church of Saint Paul, to address his majesty, King George V, and the most prominent Englishmen.

Gentlemen and friends! I spent the whole day yesterday looking at this magnificent temple, which is the pride of England and Christianity. I have seen that it has been built by using the most expensive material, brought from various parts of the empire, where the sun never sets. I have seen that it has been built from granite and marble, that the waves of the hundreds of seas and oceans rinsed them to the shore. It is also decorated with gold and precious stones, which were brought from the most valuable mines in Europe and Asia. I have convinced myself that this temple is accounted for one of the architectural wonders of the world for a reason.

However, my friends, I am coming from a little country in the Balkans, and there is a temple that is bigger, holier, and more beautiful and precious than this one. That temple is located in the Serbian town of Niš and its name is the Skull Tower. That temple is built from the skulls that belong to my people. They have been standing there for five centuries, like a stout dam for Asian sea, on the Eastern European gate. And if all the skulls and bones were used to build the temple, that temple would be three-hundred meters tall, with identical width and length, and every Serb could have come in today, raise his arm and point at each one of them 'This is the skull of my grandfather, my father, my brother my neighbour, my friend, my God-father, my best man'. For five centuries, Serbia has been defending Europe with its bones and skulls, so Europe could live peacefully.

We made the Turkish sabres blunt with our bones; we threw down the savage hordes that were rushing down like a mountain whirlwind towards Europe. Not for a decade, nor for a century, but for all those centuries between Rafael and Shearer. During all those 'white and red centuries', while Europe was experiencing religious reformation, the scientific 
revolution, political revolutions, work reformations, the reformation of the overall way of life, using words, we carried out our role with our lives. While Europe was heartily revising gods and people from the past, and while it was going through a purgatory both physically and spiritually, we, as patient slaves, were slaughtered by the European enemies, forbidding the entry into that same purgatory. In other words, while Europe was becoming Europe we know Today, we were its fence, the impenetrable wall, and the wild thorns around the gentle rose. On Vidovdan, the year 1389, Serbian tsar Lazar came to Kosovo with his brave army, on the frontier of Christian Europe, and in order to defend the Christian culture, he gave his life. At that time there were as many Serbs as Englishmen now. Today, there are ten times less Serbs than then.

Where are they? They died, protecting Europe. Now it's Europe's turn to pay back the debt."

Пет дана касније, после Велимировићевог чувеног говора Душа Србије, Николај Велимировић и Кентеберијски архиепископ су одржали заједничку службу у лондонској катедрали Светог Павла. Овај велики догађај је најављен постерима широм Лондона, а Тајмс је објавио распоред догађаја, под насловом: „За Србију, Мислите о Србији, Молите се за Србију, Обновите Србију“ ("For Serbia, Think of Serbia, Pray for Serbia, Restore Serbia”). ${ }^{17}$ Поред свечаности Видовдана, промоцију српске борбе широм Британије, подржали су „Дани заставе“ (Flag Day), организовани у многим градовима те године и у годинама до краја Великог рата.

${ }^{17}$ Dejan Djokic, "Whose Myth? Which Nation? The Serbian Kosovo Myth Revisited," in Uses and Abuses of the Middle Ages: 19th-21st Century, ed. by Janos M. Bak, Jörg Jarnut, Pierre Monnet and Bernd Schneidmueller (Munich: Wilhelm Fink, 2009), 215-233, http://research.gold.ac.uk/id/eprint/3455, https://research.gold.ac.uk/id/eprint/3455/1/Kosovomyth2.pdf, 21. 


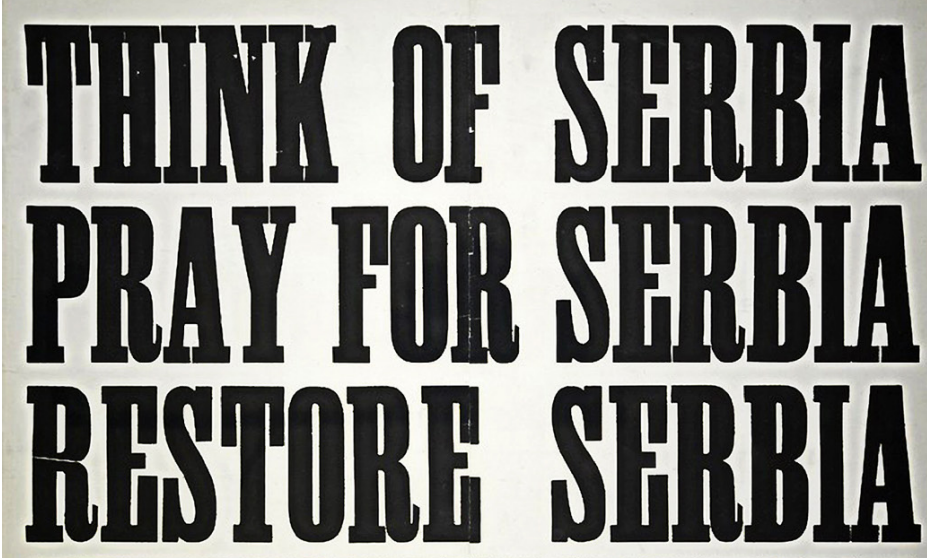

Offeo: 50, Parliament Street, Whitehall.

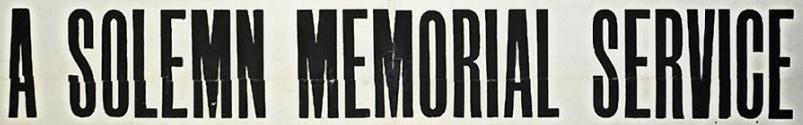

FOR ALL SERBS AND BRITISH WHO HAVE DIED IN SERBIA

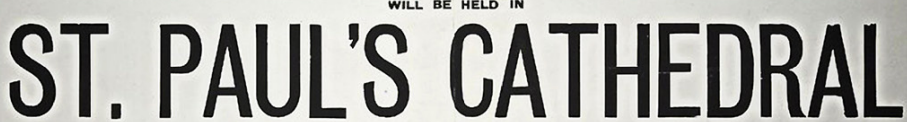
ADMISSION FREE BY WEST DOOR

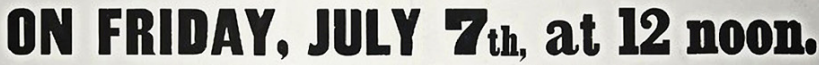
Pmeacher: LIIS GIRACE THEE

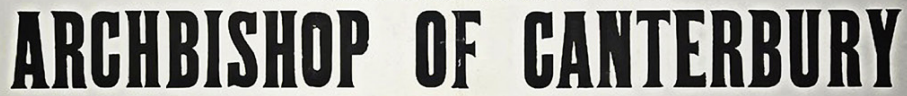

THE LORD MAYOR AND SHERIFFS will attend in State.

H.E. THE SERBIAN MINISTER, and the 300 Serbian Boys now in England, will present

SERBIA HAS FOUGHT \& SUFFERED FOR FREEDOM: HER CAUSE AND OURS ARE ONE.

LET US HONOUR HER DEAD

$$
\text { AND STAND BY HER LIVING. }
$$

Fig. 5. WWI poster: Pray for Serbia: a solemn memorial service in St. Paul's Cathedral, "H. E. the Serbian Minister [= N. Velimirovich] will be present" Сл. 5. Плакат који најављује Николајево гостовање и проповед у Катедрали Св. Павла у Лондону 7. јула 1916. г. (извор: https://velikirat.nb.rs/) 


\title{
Николај Велимировић, уредник и аутор предговора памфлета Дан Косова
}

У оквиру обележавања Видовдана (Косовског дана), 1916, у Лондону, објављена је једна историјска брошура о значају Косова у историји културолошког и историјског наслеђа српског народа. Поред британских, француских, немачких, руских историчара, укључен је отац Николај Велимировић, као аутор предговора и уредник брошуре. На корици издања Дан Косова (Kossovo Day, 1389-1916), била је слика цара Лазара. Овом Велимировићевом редовима, намењеним народу на Западу, пренета је порука о значају и историјском путоказу Косова, као извору енергије, виталности и слободе, који је био бакља, српском народу у прошлости, али светли у садашњости и светлиће у будућности.

\section{Из предговора Дана Косова (1389-1916), из пера Николаја Велимировића}

\begin{abstract}
„Упркос чињеници да Србија пати, она се смеши иронично и с надом гледа у будућност. У тренутно великом јаду, она је инспирисана сећањем на Косово. У току 500 година њеног потлаченог робовања, Србија је увек налазила у сећању на Косово велики извор енергије, виталности и слободе. Отуда у овом тренутку она се осврће на своје најславније дане у историји, на Видовдан, и наставља да живи. Непријатељи Србије, налазе извор свог постојања у њиховим фабрикама гвожђа, али извор живота Србије ће бити Божија правда и њихови савезници: Божија правда, за коју је свети цар Лазар жртвовао свој живот, и њени прави и велики савезници, међу којима је Косово најстарије и највеће надахнуће." ${ }^{18}$
\end{abstract}

18 [Nikolai Velimirovich], "Prefatory Note," Kossovo Day, 1389-1916 (London: Polsue Limited, 1916), 5. 


\section{Kossovo Day (1389-1916), Prefatory Note,}

\section{Nicholai Velimirovich}

"However, suffering Serbia smiles ironically and looks forward hopefully. In her present hour of supreme misery, she is inspired by the memory of Kossovo. During 500 years under a criminal regime Serbia found always in this memory of Kossovo an immense source of force, virtues, and life. She celebrated Kossovo Day both in the time of darkness, and in the time of light and freedom. Well, at the present moment, will look back towards her greatest day in history, towards Kossovo Day, and will live. The killers of Serbia can find a source for their life and glory only in their iron factories, but Serbia's sources of life will be God's justice and her allies; God's justice for which the saint Tsar Lazar sacrificed his life, and her true and great allies, among whom Kossovo is the oldest and most inspiring one."

\section{Српски Црвени крст у Великој Британији у време Првог светског рата}

У Првом светском рату, при Српском посланству у Лондону основан је Одбор Српског Црвеног крста, који је деловао у Великој Британији (The Serbian Red Cross in Great Britain). Истовремено, при Српском посланству је деловало неколико фондова за помоћ Србији: Фонд за рањене српске војнике (The Disabled Serbian Soldiers' Fund), Фонд Св. Јелене за ратну сирочад (The St. Helen's Relief Fund for the Orphans), Специјални фонд српског митрополита (The Special Fund of the Metropolitan of Serbia) и Српски скупштински потпорни фонд (The Serb Parliamentary Relief Committee).

Након голготе српске војске преко Црне Горе и Албаније и искрцавања на Крф крајем 1915. године, деловање српс- 
ке владе и српских институција се наставља у избеглиштву. Тако је Друштво српског Црвеног крста обновљено на Крфу, 1. маја 1916. године. Др Милош Борисављевић (1854-1934) се, у име Српског Црвеног крста, обратио за помоћ друштвима Црвеног крста пријатељских земаља широм света. Чувени апел је између осталог носио поруку: „Историја света не памти већу трагедију од оне, коју је доживео српски народ.“ Одзив је стигао од друштава Црвеног крста из Русије, Велике Британије, Француске, Швајцарске, Америке, Јапана, Холандије, Италије и других пријатељских земаља. ${ }^{19}$

При Српском посланству у Лондону, августа 1914. године основан је Пододбор Српског Црвеног крста под именом „Фонд Српског Црвеног крста“ (The Serbian Red Cross Fund). На почетку, Српски црвени крст је радио у просторијама Српског потпорног фонда са седиштем у улици Cromwell Roud, бр 5, у Јужном Кенсигтону (South Kensington). Године 1916, Српски Црвени крст у Лондону је официјално признат као огранак Српског Црвеног крста, обновљеног у то време на Крфу.

У току и након Првог светског рата, Српски Црвени крст у Великој Британији је радио с великим успехом. Главна активност је била организовање помоћи за српске ратне заробљенике у Аустроугарској, Немачкој и Бугарској и подршка цивилног становништва интернираног у непријатељске логоре. С истим залагањем, Српски Црвени крст се бринуо о српским избеглицама у савезничким земљама, посебно оним смештеним у француским болницама и санаторијумима у Француској и Северној Африци. Санитетска опрема, помоћ у храни и одећи стизала је из свих делова Велике Британије, из британских доминиона Канаде, из далеке Аустралије, Новог Зеланда и Америке.

„Никада у историји Србија није уживала већи углед у свету но што је то било у Првом светском рату“ писао

${ }^{19}$ Сйоменица 1876-1936 (Београд: Друштво Црвеног крста Краљевине Југославије, 1936), 109-122. 
је Николај Велимировић септембра 1915, поводом организовања Дана српске заставе у Енглеској: „Била је то велика радост видети како свако у Лондону, престоници света, носи српску заставу на грудима.“ Јуна идуће године на прослави Видовдана држана су предавања о Косову у $12.00 о$ британских школа, организовано је 70 митинга, химна Сpбије свирана је у свим биоскопским салама, а новине су пуњене хвалоспевима храбром малом народу у борби за слободу.

Српска химна у преводу Елизабет Христић, објављена у Тајм-

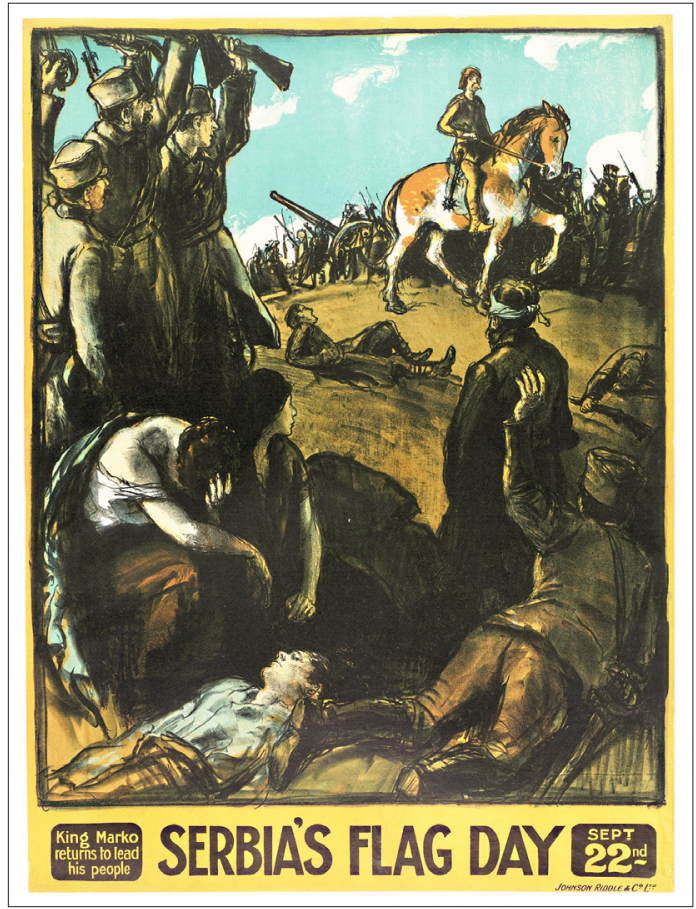

Fig. 6. WWI poster: Serbia's Flag Day

Сл. 6. Плакат за Дан српске заставе (извор: Србија данас, https://www.srbijadanas.com/) cy, певана је и свирана широм Британије. Многи светски часописи и листови преузели су текст српске химне, a ayстралијски Хоршам йајмс (The Horsham Times, Victoria, Australia) је писао: „Мада је мало позната, Српска национална химна је једна од најлепших на свету.“ (“Although very little known, the Servian National Hymn is one of the finest in the world."). ${ }^{20}$ Српску националну химну је певало 300 српске избегле деце, као пратња оца Николаја, док

20 "Servian National Hymn," translated by Elizabeth Christitch, The Horsham Times (Melbourne, 14 January. 1916): 3. Опширније: Popović Filipović, Hrabrost izmedu redova, 308. 
је држао проповед на великој меморијалној служби у Катедрали Св Павла, на Видовдан 1916. године.

Посланство Краљевине Србије у Лондону је било седиште окупљања хуманиста и прикупљања помоћи за Србију. Прво на челу с послаником господином Матејом Бошковићем (1864-1950), који је као посланик заступао Краљевину Србију у Британији, до јула 1916. године. Следило је постављење посланика господина Јована Јовановића Пижона (1859-1939),21 политичара, професора, публицисте и великог дипломате, који ће дужност обављати у периоду од јуна 1916. до децембра 1919. Дипломатска мисија Јована Јовановића у деликатно ратно време била је прожета бројним сусретима, јавним предавањима, говорима и великом пропагандном раду. С великим успехом ширио је међународне везе с другим дипломатским представништвима и друштвима Црвеног крста у време Великог рата и у послератном периоду. Као публициста оставио је велики број историографских радова о дипломатској историји Европе и историји Првог светског рата.

Маја 1917. године, Пододбор Српског Црвеног крста у Лондону признат је од стране британских власти, као ауйономно ирравно тиие, док је његово деловање било по правилима прописаним од стране Председништва Главног

${ }^{21}$ Јован М. Јовановић Пижон (1869-1939) се родио у Београду, где је завршио основну школу, гимназију и права на Великој школи 1891. године. На Универзитету у Паризу стекао је диплому из правних наука. Био је дугогодишњи дипломатски службеник у Посланству Краљевине Србије у Цариграду, Софији, Атини, Скопљу, Црној Гори, у Министарству спољних послова у Београду, Бечу и Лондону. Након великог повлачења 1915. године, постављен је за посланика Краљевине Србије у Лондону, јула 1916. Заједно с бројним српским интелектуалцима, сарађивао је с професором Ситон-Вотсоном, Артуром Евансом, Викемом Стидом, Тревељаном и другима на промоцији дипломатске, медицинске и хуманитарне помоћи за Србију. Одласком из Лондона, децембра 1919, понуђена му је служба посланика Краљевине СХС у Вашингтону, коју је он одбио и вратио се као пензионер у домовину. У Београду је основао Земљорадничку странку (1920), а као успешан политичар, биран је шест пута за посланика Народне скупштине. 


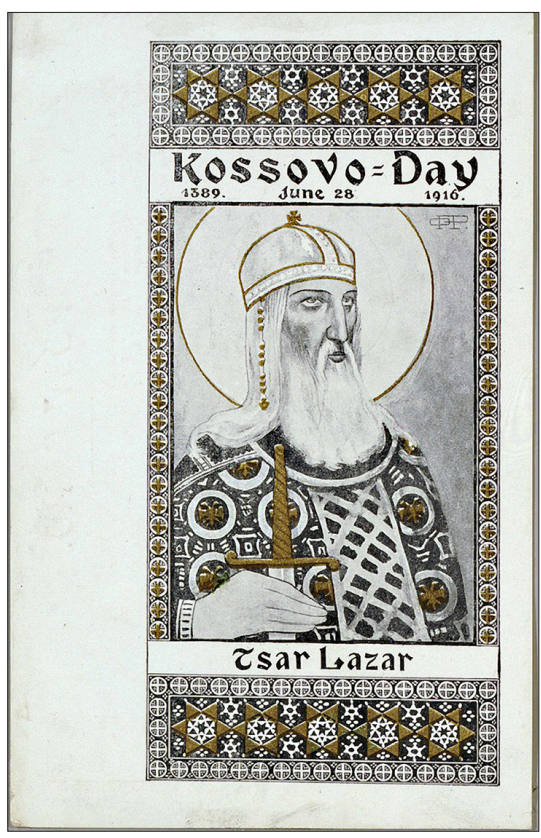

Fig. 7. Illustration from Kossovo Day, 1389-1916

(London: Polsue Limited, 1916)

Сл. 7. Илустрација из памфлета Дан Косова, 1916. г. (извор: Србија данас, https://www.srbijadanas.com/)

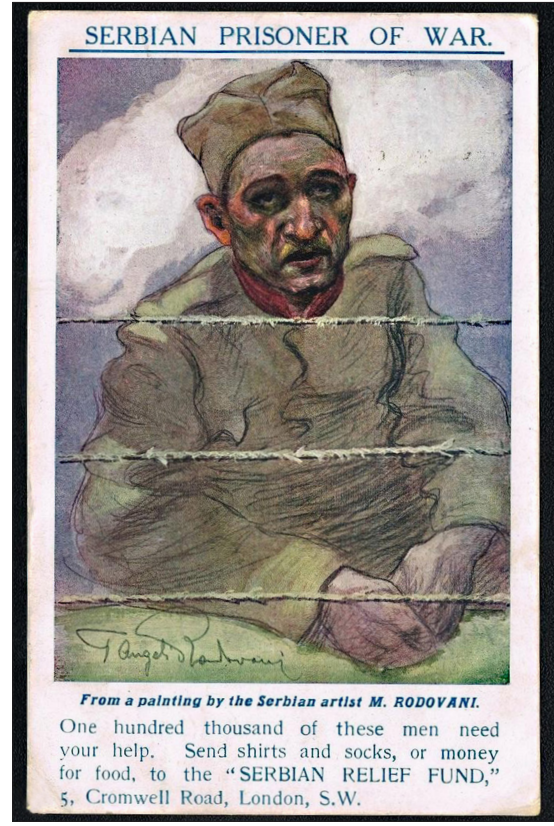

Fig. 8. WWI poster: "Serbian Prisoner of War," Serbian Relief Fund, 1916

Сл. 8. Плакат „Српски ратни заробљеник“ СПФ, (извор: Србија данас, https://www.srbijadanas.com/)

одбора Српског Црвеног крста на Крфу. На овај начин Српски Црвени крст је добио иста права као други пододбори Британског Црвеног крста, који су у то време деловали у Великој Британији (Канадски Црвени крст, Шкотски Црвени крст, Аустралијски Црвени крст).

У току и након Првог светског рата, Српски Црвени крст у Великој Британији је у својој мисији да помогне српску војску у егзилу и избегао народ широм Европе, окупио велики број високих личности, угледних дипломата, политичара и друштвених радника.

Залагањем госпође Марије Јовановић, супруге Јована M. Јовановића Пижона, основана је и радионица Српског 


\section{Serbian Philosophy and Religion.}

From "Serbia's Place in Human History," by Rev. Nichol.ss Veimurović, Professor of Theology, Belgrade University.

Q $\mathrm{C}$ ideal is not the super-man but the Al/-man. The Son of God designed the same ideal by His words, and sanctified it by His blood upon the earth. By degrees, during many centuries, this ideal was carved in the ethical consciousness of European mankind, and was in detail elaborated and accentuated by the most spiritual and most gifted men of the European and American continents: Emerson, Victor Hugo, Dickens, Tolstoi, Longfcllow, Dostoiersky, i.e, the men whose works came to be the first and most sacred after Holy Writ for nine tenths of reading people.

lccording to this philosophy, which is presented lastly more and more as the Slavonic philosophy and which

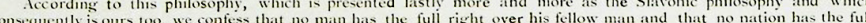
right over its fellow nnon

THE FIRST PRINCIPLE OF THIS PHILOSOPHY IS-FREEDON, THE SECOND-LOVE.

We consider ourselves not is the lords of this world. We look upon this world ts upon God's field and upon humin beings is upon God's seed. The great Sower has sown the seed upon His field. Who gave us the right to humim beings is upon God's secd. The great sower hat root it out? Who gave us the right to say : this and say : this and that seed is not good, inerefor he shalloot it out? that creature must be burnt because it is not of our colour, of our sme and of our fruterminated because it is too small; and this one must be dispersed because it is perilous; and this one must be subjugated because it speaks not our tongue and prays to God not according to our rite?

We have the right to live in this world, but also the obligation to let other people live too.

We have the right to be free, but also the obligation to make other people free.

We have the right to our daily bread, but also the obligation to take care of our hungry neighbours.

We have the right to demand the protection of our person, but also the obligation to protect people in danger.

We have the right to look upon ourselves as the sons of God and upon our nation as God's nation, but fthe obligation, too, to look upon all $m-n$ as the sons of God and upon all nations as God's nations,

W. Serbians uphold such a philosophy not because we are little but hecause this philosophy is great and sublime. The day will come when this philosophy will be generally acknowledged as the only salutary philosophy for the soul and body of human-kind. It will draw man nearer to man, nution to nation, state to state, and it will join all in one brotherhood, one love, one Kingdom of God upon the earth.
THE SERBIAN CHILDREN AND THEIR OFFICIAL NUMBERS.
15
16
Gjorgjevitch, Kronislav
Govitch. Yovan
$\begin{array}{ll}16 & \text { Gjorgevitch. Yovan } \\ 17 & \text { Gligoriyevitch, Vasiliye }\end{array}$
19 Ilitch, Tashko
20 Ilitch, Yordan
$\begin{array}{ll}25 & \text { Kostitch, Alexandar } \\ 26 & \text { Kustitch, Giorgje }\end{array}$
if Ignyatovitch, Alexandar
21 Ivanovitch, Boshko
27 Kuzmanovitch, Giorgje

18

Fig. 9. "Serbian Philosophy and Religion," an article by N. Velimirovich, from the publication Little Children of Serbia: Story of Serbian Orphan Children

Сл. 9. „Српска философија и религија“, чланак Николаја Велимировића из памфлета о српској сирочади (извор: https:/velikirat.nb.rs/)

црвеног крста у Лондону, у којој су израђивани разни одевни предмети за српски народ у земљи и избеглиштву и за заробљенике у логорима. Српски црвени крст је подржао српску омладину, која је током школовања била смештена у Ђачком дому у Лондону (Serbian Hostel, 12 Connaught Place, London W.).

Српско друштво Црвеног крста у Великој Британији деловало је под почасним покровитељством Њ. В. принцезе Кристијан (HRH Princess Christian of Schleswig-Holstein, 1846-1923), треће ћерке краљице Викторије, покровитељством Њ. В. Александра Карађорђевића, док је почас- 
ни председник био Пол Камбон (Paul Cambon), француски амбасадор у Лондону, председник његова екселенција посланик Јован Јовановић Пижон, председавајући Франк Хејстингс (Mr. Frank Hastings), вршилац дужности почасни благајник Павле Митровић. Потпредседници су били: принцеза Дарја Прат (Daria Pankhurst Wright Pratt, Karageorgevich),22 супруга принца Алексе Карађорђевића, гроф Балфор (Earl Balfour), сер Џорџ Битон (Sir George Beaton), др Милош Борисављевић, архиепископ Кентерберија, сер Едвард Купер (Sir Edward Ernest Cooper), леди Купер (Lady Cooper), грофица Каудри (Lady Pearson Cowdray), др Милан Ћурчин, грофица Curzon of Keldeston, санитетски генерал др Чедомир Ђурђевић са супругом Видом Балаицки Ђурђевић, др Ђока Ђурић, гроф и грофица Ашер (Lord Esher i Lady Esher), госпођа Роберт Френк (Mrs. Robert Frank), мадам Стојанка Гавриловић (супруга Михајла Гавриловића), професор Тихомир Ђорђевић, сер Чарлс Грац (Sir Charles Louis des Graz), његова екселенција амбасадор Грчке, др Лазар Генчић, пуковник Чарлс Хоџитс (Colonel Charles Hodgets), господин Настас Илић, госпођа Гертруда Кинел (Mrs. Gertruda Kinnell), мадам Станка Лозанић (супруга проф. Симе Лозанића), Lord Bishop of London, Lady Leconfield, пуковник Ноел Маршал (Noel G. L. Marshall), мадам Мису (Madame Misu), Дон Луис Митровић (Don Louis Mitrovitch), господин Павле Митровић, др Џејмс Морисон, хирург (Dr. James Thomas Jackman Morrison), сер Џорџ Пер-

\footnotetext{
22 Дарија Прат Карађорђевић (Daria Pankhurst Wright Pratt, Karageorgevich, 1859-1938), Американка, голф играчица, била је позната као добитник бронзане медаље на Олимпијским играма 190о. Дарија је заједно са супругом Алексом Карађорђевићем, опремила и финансијски подржала једну болницу, која је у време Великог рата радила у Врњачкој бањи. Они су из Швајцарске послали материјалну помоћ у износу од 20.000 франака, као прилог сакупљен на Српској изложби у Лондону. Дарија Прат, активна чланица Пододбора Српског Црвеног крста и Алекса Карађорђевић, члан Српског Црвеног крста су учествовали у многим активностима у организовању доброчинства у корист Србије. У време егзодуса српске војске и санитета, били су у Србији, па тако су искусили српску голготу преко Албаније.
} 
ли (Sir George H. Perley), професор Богдан Поповић, сер Битон Роудц (Sir R. Beaton Rhodes), његова екселенција амбасадор Румуније, војвода Ратленд (Duke Rutland), војвоткиња Ратленд (Duchess Rutland), отац Николај Велимировић, др Роман Сондермајер, др Војислав Субботић, сер Артур Стенли (Sir Arthur Stanley), леди Свејтлинг (Lady Swaythling), капетан Јован Тановић, леди Вајтхед (Lady Whitehead), ${ }^{23}$ професор и преводилац Џејмс Вајлс (James William Wiles), ca супругом госпођом Луиз Вајлс (Mrs. Louise Wiles), леди Виндхем (Lady Wyndham) и леди Јанг (Lady Young).

Одбор Српског Црвеног крста су чинили: капетан Павле Алексић, његова екселенција Михајло Гавриловић са супругом Стојанком Гавриловић, Павле Митровић, Л. Г. Лаијевић, дипломата Чедомиљ Мијатовић, ${ }^{24}$ пуковник Г. П.

23 Леди Вајтхед (Lady Marian Cecilia Brodick Whitehead, 1869-1932), била је ћерка грофа Мидлетона, а супруга британског дипломате сер Џејмса Вајтхеда (Sir James Beethon Whitehead, 1858-1928), који је службовао у Toкију, Брислу, Константинопољу, Берлину. Леди Вајтхед је боравила у Београду, у пратњи супруга Вајтхеда, британског посланика у Србији, у периоду 1906-1910. Инцијативом леди Вајтхед, 1912. године основан је Балкански комитет енглеских госпођа, који је имао неколико пододбора. Српски одбор је за председницу имао леди Монд (Violet Florence Mabel Melchett, Lady Mond), која се истакла у помагању српским рањеницима, снабдевањем одећом и новцем, као и помоћи породицама војника на фронту. У време Првог светског рата, леди Вајтхед је била чланица Пододбора Српског Црвеног крста у Лондону, где је дала велики допринос у доброчинству за српски народ.

24 Чедомиљ Мијатовић (Chedomille Miyatovich, 1842-1932), књижевник, историчар, публициста, економиста и дипломата, био је један од познатих личности Србије 19. века. После завршеног Лицеја у Београду (1862), студирао је у Минхену, Лајпцигу, Цириху и Бечу. Као изузетан економиста, поставио је темеље модерној, европски оријентисаној Србији, заслужан је за увођење динарског и метарског система, поставио темеље народне банке и железнице у Србији. Мијатовић је шест пута био министар финасија Кнежевине/Краљевине Србије, у три мандата био министар иностраних дела, међу првима постао члан Српске краљевске академије и њен други председник. Од 1895-1903, био је српски посланик у Цариграду, а најдуже у Лондону, где је приватно живео од 1889. Као историчар и књижевник, Мијатовић је објавио бројна дела на српском (19) и енглеском језику (6), а најпознатија су Србија и Срби (Chedo Mijatovich, Servia and Servians 
Остојић, мајор Милан А. Јовичић (син Александра Јовичића, дипломате), Владимир Јовановић, госпођа Марија Јовановић (супруга Јована Јовановића Пижона). ${ }^{25}$

Српски Црвени крст у Лондону имао је велику помоћ и подршку сер Џона Бранера, познатог политичара, члана Парламента и филантропа. Сер Џон Бранер (Sir John Tomlinson Brunner, 1842-1919) је био власник највеће британске компаније у хемијској индустрији (Brunner \& Mond Company), који је српском друштву уступио своју лондонску кућу на коришћење, а он се повукао на породично имање. Тако је Српско друштво Црвеног крста, уз благослов оца Николаја Велимировића, свечано започео да ради у вишеспратној згради на адреси 9, Ennismore Gardens, London, S.W.7.

\section{Болнице шкотских жена у Србији и са Србима у егзилу}

Почетак двадесетог века је свој долазак широм света обележио великим женским покретом за равноправност жена с мушкарцима, по праву гласа, једнакости при избору професија, истим правима у образовању, подједнакој здравственој заштити. Талас женске еманципације, који је потекао из Америке, проширио се на Европу, све континенте, стигао до удаљених делова Аустралије и Новог Зеланда.

(London: I. Pitman and Sons, 1908)) и Усйомене јеgної балканскої gийломайе (Mijatovich, The Memoirs). Мијатовић је био први Србин именован за сарадника Енциклопедије Британике. Био је ожењен Енглескињом, Елодијом Лотон (Elodie Lawton, 1825-1908), која је била прва жена историчар код нас, а аутор Истиорије моgерне Србије (Elodie Lawton Mijatovics, The History of Modern Serbia (London: W. Tweedie, 1872)), написала први уџбеник за нудиље, била преводилац великог броја српских кратких прича и српских епских песама. Опширније: Слободан Г. Марковић, Гроб Чеgомиљь Мијайовић: Викӣоријанаи међу Србима, Библиотека „Животописи“, књ. 1 (Београд: Досије - Правни факултет, Центар за публикације, 2006).

${ }^{25}$ Списак чланова Српског Црвеног крста у Великој Британији преузет је из: Milan G. Miloyevitch, Anglo-Yugoslav Cultural Relations (London: St. Clement's Press, 1944), 52-54. 
Међу истакнутим сифражеткињама у борби за женска права била је др Елси Мод Инглис (Dr. Elsie Maud Inglis), ${ }^{26}$ Шкотланђанка, која је именована за почасног секретара Шкотске федерације удружења жена сифражеткиња (the Scottish Federation of Women's Suffrage Societies). Уз помоћ овог удружења крајем 1914. године, др Инглис оснива Болницу шкотских жена за службу у иностранству (the Scottish Women's Hospitals for foreign service). Како нису добиле поверење у домовини, Болнице шкотских жена, које су се обратиле савезницима и биле прихваћене у Француској, Белгији, Србији, Румунији, Русији и на Малти.

Од десет формираних јединица Болнице шкотских жена, намењених српском народу, четири болнице су радиле у Србији: у Крагујевцу, Ваљеву, Младеновцу и Лазаревцу, наставиле у окупираном Крушевцу, а по ослобођењу земље, радиле у Врању и Београду. Болнице шкотских жена нису само дошле у помоћ српском санитету у Србији, већ су пратиле Србе на свим фронтовима. Тако су формирале три болнице, које ће деловати на Солунском фронту (у Сoлуну, Острову и Вербилијани), по једна на Руском фронту и Добруџи (Јединица Лондон), на Корзици (Ајачијо) и

\footnotetext{
26 Др Елси Инглис (Dr. Elsie Inglis, 1864-1917) је била лекарка, хирург, велики визионар и оснивач Болнице шкотских жена, јединствене медицинске формације у Првом светском рату. Др Елси Мод Инглис пореклом Шкотланђанка, рођена је у Нини Тал, у подножју Хималаја у Индији, одрасла на Тасманији. Елси Инглис је међу првим женама дипломирала медицину и хирургију на Краљевском колеџу за лекаре и хирурге у Единбургу (The Royal College of Physicians and Surgeons, Edinburgh) и на Факултету за лекаре и хирурге, у Глазгову (The Faculty of Physicians and Surgeons, Glasgow). Лиценцу лекара је стекла у Единбургу, августа 1892. године, а након положених испита добила је троструку квалификацију лекара. Лекарску каријеру започела је у „Елизабет Гарет Андерсон Новој болници за жене“ (Elizabeth Garett Anderson’s New Hospital for Women), у Лондону, али убрзо је изабрана за предавача за гинекологију на Медицинском колеџу за жене у Единбургу. Као велики борац за подједнака академска права жена, изабрана је за секретара Шкотске федерације удружења жена сифражеткиња, уз чију помоћ и подршку оснива Болницу шкотских жена. Била је то прва женска болница, која с пуним правом заузима посебно место у историји медицине и историји Великог рата.
} 
у Француској (Саланше). Болнице шкотских жена су биле праћене самосталним Транспортним јединицама, две јединице су деловале на Солунском фронту, а трећа у пратњи Прве српске добровољачке дивизије деловала је на Руском фронту и Добруџи. Болничко особље у искључиво женском саставу, долазило је из свих крајева Велике Британије, Аустралије, Новог Зеланда, Канаде, Америке, а било је и британских поданица из Индије.

Др Елси Инглис, хирург, лекарка с троструком квалификацијом, дошла је у Србију, да преузме управу Прве јединице Болнице шкотских жена, лечила српске војнике у Крагујевцу, а у повлачењу одбила да напусти своју болничку дужност, већ наставила да ради у окупираном Крушевцу. Приликом свог боравка у Србији, др Елси Инглис, спиритус мовенс у оснивању и деловању Болнице шкотских жена, упознала је српски народ, а своја дивљења записала:

„Видите, ми се налазимо у врло тужној земљи, али то је најодважнија земља у Европи, без изузетка. Овде њихови најбољи људи страдају на све стране, али никад се не жале и никад не помисле ни за тренутак да се предају, иако Аустријанци још увек могу да нагрну. Аустрија их је страшно лоше третирала, али Срби нису огорчени на њих. Срби се односе према непријатељским затвореницима на потпуно исти начин као према својима, мада немају много шта да им понуде. Србија је јако поносна земља, па отуда не воли да је други народи жале. Она је дивна мала земља, и ми смо је већ заволели, али је скроз опустошена с три последња рата. Тако ми имамо војнике у нашој болници који су скоро само дечаци, али који поносно показују своје ожиљке - од Турака, Бугара и сад од Аустријанаца“.27

${ }^{27}$ Slavica Popović Filipović, Dr Elsie Maude Inglis: The Serbian Mother from Scotland, 1917-2017 (Valjevo: Istorijski arhiv, 2017), 22. 
["You see we are in a very sad country, but it is the pluckiest country in Europe, without exception. Here they are with their best men perishing on every side, and they make no complaint, and never think for a moment of giving in, though the Austrians may be down on them yet. Austria has treated them abominably, and yet they are not bitter. Their prisoners get the same treatment - miserable though it is - as their own men do. Serbia is as proud as it is possible to be and does not want other countries to pity them. She is a grand little country, and we all love her already, but she is desolate with her three wars. Why, we have men in our Hospital almost boys, who proudly show their three scars — Turkish, Bulgarian, and now Austrian.”]

„Кажем вам да су ови људи прави дивови. Осећам се тако малом поред њих да би требало да се сакријем. Бол! Испаштање! Нисте упознали храброст док не видите ове људе како испаштају. Ампутирала бих нечију шаку, руку или ногу, и то без анестетика - и да ли се тај помери? Не, ни да трепне. Највише што можете да очекујете да чујете од таквог пацијента је: „Куку леле“ и то је све. А онда издахну! Често издахну без вапаја и без иједне речи. Понекад, можда само изусте једно „хвала“ и то је све. Стварно не знам одакле долази ова раса ратника, али могу да вам кажем да су они Божји људи. “28

["I tell you these men are great. I feel so small beside them that I could hide myself. Pain! Suffering! You've not seen bravery until you've seen these men suffer. I'd take off a hand, an arm, or a leg - without anesthetics, mind you - and will the fellow budge? no, not an eyelid. And if you hear them say 'Kuku lele' (Oh dear!) that's as much as you hear, and not often that much. They'll die without a sound - unless it is to thank you, if they can, before they go. Where this race of soldiers was sprang from? I don't pretend to know, but I tell you right now they are God's own men."]

${ }^{28}$ Popović Filipović, Hrabrost između redova, 188-207. 
Трећа јединица Болнице шкотских жена у Младеновцу, деловала је под руководством др Битрис Ен МекГрегор (Dr. Beatrice Ann MacGregor, 1873-1953), Шкотланђанке из Њуингтона (Newington, Edinburgh, Scotland). ${ }^{29}$ Болница шкотских жена у Младеновцу је имала 400 постеља, а с јењавањем епидемије др МекГрегор је отворила диспанзер за мајку и дете. Диспанзер у Младеновцу је био јако посећен од стране локалног становништва, јер је за две недеље прегледано око 7оо пацијената.

У знак сећања на велику хуманост и медицинску помоћ чланицама Болнице шкотских жена и њеном оснивачу и лидеру др Елси Инглис, српски војници су септембра 1915. године изградили меморијалну чесму на Црквенцу, у Младеновцу, на којој је урезан натпис:

За успомену на санитарне мисије шкотских жена у Србији и њиног оснивача Dr Елзе Инглис

(In Memory of the Scottish Women's Hospitals in Serbia and Their Founder, Dr. Elsie Inglis).

Спомен чесма је свечано отворена у присуству др Елси Инглис, чланица Болнице шкотских жена и великог броја војника Моравске дивизије I позива. Српски официр В. Поповић, који је направио нацрт споменика, том приликом је рекао:

„Ако точак времена разруши овај споменик, постоји друго знамење створено у срцима српског народа и војника, које ће вечно чувати сећање на хумана дела Шкотских жена и др Елси Инглис.“

[“The Serbian officer V. Popović, who designed the monument said at the Ceremony: 'If the pitiless wheel of time crushes the

${ }^{29}$ Eva Shaw McLaren, ed., A History of the Scottish Women's Hospitals (London: Hodder and Stoughton, 1919), 108. 
monument, there is yet another one created in the hearts of the soldiers and Serbian People."'30]

Меморијалну чесму на Црквенцу су освештала петорица српских свештеника, а по обреду др Инглис је добила струк босиљка, који је с Орденом Светог Саве сачувала као највеће драгоцености. Поред овог знамења српске традиције, др Елси Инглис је у домовину понела многа сазнања о српском историјском наслеђу.

Октобра 1915. године, када су српска војска, српски војни санитет и народ пошли у велико повлачење, поносна Шкотланђанка је одбила да се повуче. Др Инглис је с делом особља прешла у Крушевац и наставила своју лекарску мисију у Болници Цар Лазар, која је примила преко хиљаду тешких рањеника и болесника. После вишемесечног рада у окупираном граду, у пролеће 1916, извршена је репатријација др Инглис и чланица Болнице шкотских жена преко Швајцарске. Све ратне страхоте, које је др Инглис са српским народом поделила у Србији, допринели су да она буде међу првима, која ће покренути идеју обележавања Дана Косова (Видовдана) у Лондону и широм Британије. Уз помоћ Лондонског комитета Болнице шкотских жена, многе чланице су допринеле промоцији српске историје, пре свега говорима и сведочењима о ратним страхотама и страдањима у Србији. Истовремено, др Елси Инглис се ангажовала у организовању Дана заставе (Flag Day), српског патриотског краља, који се у Лондону одржао у року од шест недеља. Пракса Дана заставе се проширила од југа до севера Британије и постала један од видова сакупљања помоћи за Србију.

Непоуздано је када је дошло до сусрета др Елси Инглис и оца Николаја Велимировића. Једна од могућности је ап-

\footnotetext{
30 Slavica Popović-Filipović, Za hrabrost i humanost, Bolnice škotskih žena u Srbiji i sa Srbima za vreme Prvog svetskog rata 1914-1918 (Beograd: Signature, 2007).
} 
рил 1916, када је принц Александар Карађорђевић посетио Лондон, на пријему код краља Џорџа V и других високих британских политичара. На једном свечаном скупу, принц Карађорђевић је, у име Српске владе, уручио одликовања заслужним британским лекарима, медицинским сестрама и другим хуманистима. Том приликом српски принц је одликовао др Инглис Орденом Белог орла. Тако је др Инглис и официјално постала прва жена, која је понела ово високо српско одликовање. Орден Белог орла понеле су још две Шкотланђанке, чланице Болнице шкотских жена у току рата и у послератном периоду. Биле су то др Изабел Емзли, леди Хатон (Dr. Isabel Emslie, Lady Hutton) и баронеса Евелина Хаверфилд (Honorable Evelina Haverfield). Познато је да је отац Николај Велимировић имао лепу сарадњу с др Елси Инглис и Евелином Хаверфилд у организовању Видовдана, а с баронесом Хаверфилд је и наставио у Бајиној Башти, у послератном периоду при отварању Дечијег сиротишта.

Болница шкотских жена на Руском фронту и Добруџи, на челу с др Елси Инглис је, у пратњи Српске добровољачке дивизије, деловала од августа 1916. до новембра 1917. године. Чланице Болнице шкотских жена су пожртвовано збрињавале рањене и болесне у великим борбама, које су резултирале са 2.613 погинулих и 7.370 рањених војника. По избијању Руске револуције 1917. године, британске власти су упутиле наредбу др Елси Инглис да повуче Болницу шкотских жена и сво особље врати у домовину. Она је одбила наређење да се повуче и условила да се прво омогући слободан пролаз Српске добровољачке дивизије с Руског на Солунски фронт. По повратку у Шкотску, мада болесна и исцрпљена, др Инглис је извршила смотру српске јединице у Глазгову. Др Елси Инглис је преминула 26. новембра 1917. у Глазгову и сахрањена је са свим војним почастима на Гробљу Дин, у Единбургу (Dean Cemetery Edinburgh), уз присуство представника британске, француске и српске војске. Отац Николај Велимировић је са српским ученицима из единбуршке школе Џорџ Хериот, одржао по- 
следњи помен храброј Елси Инглис у Катедрали Светог Гила у Единбургу (St. Giles' Cathedral, Edinburgh).

\section{Српски потпорни фонд у помоћ Србији у току рата и у послератном периоду}

Једна од најуспешнијих хуманитарних организација, која је помогла Србију у време Првог светског рата и у послератном периоду био је Српски потпорни фонд. Деловање Српског потпорног фонда, основаног у Лондону, 23. септембра 1914, трајало је до 1921, а неке акције чак и до 1953. године. Мисија СПФ у току рата и у послератном периоду одржавана је добровољним прилозима из: Канаде, Аустралије, Новог Зеланда, Индије и Јужне Африке. Донацијама је прикупљено укупно 790.000 фунти, а у санитетском и другом материјалу у вредности од 250.000 фунти. Од оснивања па до краја свог деловања Српски потпорни фонд је радио као независно хуманитарно друштво, којим је председавао Комитет у Британији и другим земљама, чланицама у иностранству.

Српски потпорни фонд је у историји филантропије Првог светског рата имао посебно место у организовању добротворног рада за Србију и Србе у избеглиштву. У друштву с преко 700 чланова тешко је одредити величину доприноса бројних чланова, али заслуга свакако припада хуманистима, који су године свог живота посветили успешном раду фонда, у корист српског народа. Међу њима су Вилијам Ситон-Вотсон (Mr. William Seton-Watson), госпођа Меј Ситон-Вотсон (Mrs. May Seton-Watson), леди Бојл (Lady Boyle), сер Едвард Бојл (Sir Edward Boyle), леди Лејла Пеџет (Lady Paget), госпођа Мабел Стобарт (Mrs. Mabel Stobart), госпођа Гертруда Карингтон Вајлд (Mrs. Gertrude Carrington Wild), леди Гроган (Lady Ellinor Grogan). ${ }^{31}$

31 Леди Елинор Гроган (Lady Ellinor Flora Bosworth Smith Grogan, 18651948), ћерка Reginald Bosworth Smith, била је удата за Sir Edward Ian Baresford Grogan, $2^{\text {nd }}$ Baronet (1873-1927), Ирца, који је службовао као официр у бри- 
У току Првог светског рата и по ослобођењу, Српски потпорни фонд је мењао своје циљеве, зависно од потреба у Србији: од првих хируршких болница до медицинских екипа за лечење инфективних болести у време велике епидемије тифуса, материјалне помоћи српском народу у окупираној земљи, у лечењу изнемоглих након повлачења, евакуацији и смештају избеглица, заштити заробљеника и интернираних цивила у логорима, прихватање и школовање српских ученика и студената, у обнављању разрушене земље након ослобођења. Тако је деловање Српског потпорног фонда почело своју мисију у Србији, наставило на Србима у егзилу, на Крфу и Солунском фронту, у Тунису, Алжиру, Мароку и Француској, на Корзици, у Великој Британији, а по ослобођењу поново у Србији.

Српски потпорни фонд је послао пет најсавременије опремљених болничких јединица у Србију крајем 1914. и почетком 1915. године, које су биле велика санитетска помоћ српској војсци и народу у време епидемије, пегавог, повратног и трбушног тифуса, а болнице су деловале у Скопљу (Прва и Друга јединица СПФ), у Крагујевцу (Трећа јединица СПФ), у Београду (Четврта јединица СПФ), у Пожаревцу (Пета јединица СПФ), на Крфу (Шеста јединица СПФ), која је као мешовита енглеско-српска болница деловала на Солунском фронту, а по ослобођењу прешла у Ниш.

танској војсци. У време Првог светског рата, леди Гроган је, као председница Извршног комитета СПФ, била задужена за ангажовање медицинског и другог особља и организовање болничке службе у јединицама СПФ. Леди Гроган је на тај начин дала велики допринос у болницама СПФ (5 јединица), које су деловале у Србији у току рата, а посебно у Шестој јединици СПФ, која је радила на Крфу. У мисији СПФ, леди Гроган је примила хиљаде писама из земље и иностранства, која су стизала на адресу: Ellinor W.S. Grogan, Chairman of the Stuff Sub-Committee, The Serbian Relief Fund, 5 Cromwell Road, London SW7. Леди Гроган је такође позната као аутор мемоара (уп. Lady Grogan [= Ellinor Flora Bosworth Smith], Reginald Bosworth Smith: A Memoir (London: J. Nisbet \& Co., limited, 1909); Lady Ellinor Flora Bosworth Smith Grogan, The Life of J. D. Bourchier (London: Hurst \& Blackett, Limited, 1926)). 


\section{Леди Лејла Пеџет, верна Србима до краја}

Новембра 1914, три месеца по избијању Првог светског рата, Српски потпорни фонда је Србији послао прву медицинску помоћ, преко Прве јединице Српског потпорног фонда (The First Unit of the Serbian Relef Fund). Прва јединица Српског потпорног фонда с 50 чланова, под управом леди Пеџет, деловала је у Скопљу. Леди Лејла Пеџет (Louise Margaret Leila Wemyss-Lady Paget), ${ }^{32}$ је боравила у Београду од 1910. године, као супруга сер Ралф Пеџета (Sir Ralph Paget), британског посланика у Србији, а у Великом рату комесара британске владе у Србији и члана Међународног одбора за сузбијање епидемије тифуса у Србији. Леди Пеџет је у Београду, у време Првог балканског рата, радила као добровољна болничарка у IV београдској резервној болници, а у Другом балканском рату основала и водила малу резервну болницу у Савамали. У Скопљу, од новембра 1914. године, Леди Пеџет је била руководилац и бол-

32 Леди Лејла Пеџет (Dame Lady Louise Margaret Leila Wemyss Paget, 1881-1958) је била ћерка генерала сер Артура Пеџета (General Sir Arthur Henry Fitzroy Paget), а супруга британског дипломате сер Ралфа Пеџета (Sir Ralph Paget), велики хуманиста и добровољна болничарка у Србији у време балканских и Првог светског рата. Међу првима подржала је оснивање Српског потпорног фонда, у Лондону, септембра 1914. Као руководилац Прве јединице СПФ у Скопљу, дошла је у помоћ Србији (новембра 1914), у време велике епидемије три тифуса. У великом повлачењу, одбила је да напусти болницу у Скопљу, па је тако са својим особљем наставила да ради у време окупације. Леди Пеџет је остала верна српском народу у рату и миру, до краја свог живота. У знак сећања на њено доброчинство у ослободилачким ратовима, име Леди Пеџет је понела једна улица у Београду. Леди Пеџет је носилац Ордена Светог Саве, првог степена с лентом, Великог витешког крста (Knight Grand Cross), Ордена Британске империје (The Order of British Empire), Медаље части Федерације Женских удружења града Њујорка (Medal of Honor of the Federation of Women's Clubs of New York City). Леди Пеџет је проглашена за Даму Beлике Британије (Dame Grand Cross), а Српска Православна Црква у Лондону је, у име њене племените мисије човекољубља за српски народ, формирала Меморијалну собу Леди Пеџет при Цркви Светог Саве, у Дому Епископа Николаја. 
ничарка Прве јединице СПФ у време епидемије трбушног, повратног и пегавог тифуса, када је и сама оболела од тифуса. Леди Пеџет је затражила помоћ од Одбора СПФ у Лондону, па тако је фебруара 1915, у Скопље стигла Друга јединица Српског потпорног фонда (The Second Unit of the Serbian Relief Fund - Lady Cornelia Wimbourne Unit), која је добила име по оснивачу леди Корнелији Вимборн (Lady Cornelia Wimborne, 1847-1927). Тако је медицинску мисију СПФ за Србију, подржала леди Вимборн, баронеса Марлборо (Marlborough), блиска рођака Винстона Черчила.

По опоравку у домовини, Леди Пеџет се вратила својој болници у Скопљу, коју није напустила ни у време окупације, када је поред медицинске помоћи становницима града и околине, примила и збринула велики број избеглица. По репатријацији, Леди Пеџет помаже обележавање Видовдана у Великој Британији, држи говоре у Лондону и Бирмингему. Српски потпорни фонд у Лондону, место човекољубља, истовремено је место сусрета, где Леди Пеџет упознаје оца Николаја Велимировића, подржава његове активности или боље речено следи његову хришћанску мисију.

Леди Пеџет је до краја остала верна српском народу, у обнови земље и помоћи народу у послератном периоду, у збрињавању ратних сирочића, у изградњи српске православне Цркве Св. Саве у Лондону, у збрињавању и лечењу српских избеглица после Другог светског рата. Пријатељи леди Пеџет из периода Великог рата, нису је заборавили ни после Другог светског рата, четвртог рата у њеном животу. Међу њеним верним српским пријатељима били су др Слободан Јовановић, др Милан Ђ. Милојевић, мајор Милан А. Јовичић, Божидар Пепић, Владика Иринеј Ђорђевић, пуковник Драгутин Савић, Вана Ивановић, адвокат Божидар Влајић, др Нико Мирошевић Сорго, протојереј Милоје Николић и многи други.

Али вратимо се Великом рату и препустимо глас Леди Пеџет, који је сачуван у њеним сећањима $C a$ нашим 
срйским савезницима (With Our Serbian Allies), у издању Српског потпорног фонда, у Лондону, 1915.

„Српски народ је веровао у своје моћне савезнике. У данима Макензеновог налета очекивао их је, али узалуд и једна од најстрашнијих трагедија одиграла се над човечанством, хомеровским витезима српског народа. У својим данима искушења, Србија је остала сама. Нападнута је једноставно с три стране, од три непријатеља. Није јој остао други излаз до да се упути непроходним, леденим врлетима дивље Албаније. Ни смрт, ни мучеништво, ни разочарења не беху у стању да скрхају онај непобедиви хероизам у души српског војника. У повлачењу остало је 150.000 мученика само у Албанији; колона сломљених хероја корачала је из пораза у пораз. Но њен војник не прима поразе, уздиже се изнад бола, не жали се, трпи: као борац, коме нема равна, он верује и пева, зато поштујем и дивим се српском војнику. Многе земље могу имати добре војнике, али сумњам да се могу похвалити борцем који би ратовао, задовољан једним хлебом недељно. Савезници и сами увиђају да је таквом народу суђено да у будућности игра на Балкану већу улогу но што ју је имао у прошлости. “33

["The Serbian people believed in its mighty Allies. At the time of the Makenzen Invasion they expected their Allies to arrive, but they never did, so one of the greatest tragedies occurred to the humane, Homeric knights of the Serbian people. At the time of its greatest need Serbia was left all alone. She was attacked simultaneously from three sides by three different enemies. There was no other alternative but to retreat through unpassable paths over the frozen Badlands of rugged Albania. Neither death, nor sacrifice, nor disillusionment were able to crash/obliterate that undefeated heroism in the hearts of the

${ }^{33}$ Lady Paget, With Our Serbian Allies (London: The Serbian Relief Fund, 1915). 
Serbian soldiers. During that retreat, some 150.000 Serbs perished in Albania alone, the columns of broken heroes stumbled from one defeat to the next. But their soldier does not know for a defeat, he overcomes the pain, he does not complain, he bears it all - as a fighter who has no equal, he believes and sings and carries on - and that is why I appreciate and admire the Serbian soldier. Many countries have good soldiers, but I doubt that they would have such fighters who would gladly fight on, contended with one loaf of bread per week. The Allies now realise that such a nation is bound to play a bigger role in the Balkans than what it had in the past."]

\section{Жене Србије, предговор леди Лејле Пеџет}

„Замољена сам да напишем уводну реч за предавање мадам Копленд и мени је драго да то чиним, мада сматрам да предавању није потребна препорука с моје стране. Историја Србије је предмет, коме је мадам Копленд посветила много проучавања и ја не могу да се правим да имам знање као она. Међутим, ја могу да говорим као неко ко интимно познаје Србију данас и ко је, с блиским милосрђем, био сведок хероизма њеног народа у лицу најсвирепије агоније, које једна нација може да пропати; због овога, њено предавање ме јако позива, и оно мора исто тако да позива и друге, јер нико од нас, сигурно, није успео а да се духовно не одазове на неописив патос трагедије Србије.

Многи од нас знају врло мало о прошлости Србије и треба да мисле о њој као да се појавила на светлост света, када је збацила турски јарам. Госпођа Копленд нас подсећа да је Србија била велика земља, са сопственом цивилизацијом, пре него што је пала под окупацију Турака, а посебна тема предавања ће нас најбоље подсетити на ову чињеницу, као што је Џорџ Мередит рекао, да је 
положај жене у сваком друштву тест њене цивилизације. У српској историји ми налазимо жене хероје, које не запостављају своје домаће дужности и обавезе, већ такође преузимају неустрашиву и непоколебљиву улогу у борбама своје отаџбине, а прикази који следе, укратко, остављају живе слике у нашем памћењу, слике храбрости и оданости, вредне потомака ових храбрих жена.“

\section{The Women of Serbia, the Preface by Leila Paget}

"I have been asked to write a preface word to Mme. Copeland lecture, and I am glad indeed to do so, although I feel it needs no recommendation on my part.

The History of Serbia is a subject to which Mme. Copeland has evidently devoted much study, and I cannot in any way pretend to knowledge such as hers. I can speak, however, as one who knows Serbia of the present day intimately, and has witnessed, at close quarters, the heroism of her people in face of the most cruel agony that any nation has been called upon to suffer; because of this, her lecture strongly appeals to me, and it must likewise appeal to others, for none of us, surely, has failed to respond in spirit to the unspeakable pathos of Serbia's tragedy.

Most of us know very little of Serbia's past, and are to think of her as emerging for the first time into the light of the world, when she cast off the yoke of the Turks. Mme. Copeland reminds us that she (Serbia) was a great country, with a civilization of her own, before ever she came under Turkish domination, and the special subject of the lecture is the best possible reminder of this fact, if, as George Meredith thought, the position of women in any society is the test of its civilization. Here we find heroic women, not neglecting their proper duties and services, but taking also a bold and 
unflinching part in the struggles of their country, and the sketches which follow, brief as they are, leave vivid pictures on our minds, pictures of courage and devotion worthy of these brave women's descendants." ${ }^{34}$

\section{Госпођа Мабел Стобарт, пријатељ Срба у рату и миру}

Као што је познато многе чланице Српског потпорног фонда су остале верне Србији и у послератном периоду. Један од њих је била госпођа Мабел Стобарт, која је по повратку из Србије наставила промоцију за помоћ српском народу, широм Велике Британије, Канаде и Америке. Госпођа Мабел Синклер Стобарт (Mrs. Mabel St. Clair Stobart, 18621954), ${ }^{35}$ је дошла у Србију у пролеће 1915. године, као руководилац Треће јединице Српског потпорног фонда (The Third Unit of the Serbian Relief Fund), која је деловала у Крагујевцу.

\footnotetext{
${ }^{34}$ Copeland, The Women of Serbia, i-ii.

${ }^{35}$ Госпођа Мабел Ен Стобарт (Mrs. Mabel Anne St. Clair Stobart, 1862-1954)
} била је позната британска сифражеткиња и хуманитарна радница. Госпођа Мабел Стобарт (девојачко Mabel Annie Boulton), рођена је 3. фебруара 1862. године, од оца сер Самуела Болтона (Sir Samuel Bagster Boulton) и мајке Coфије Луиз Купер (Sophia Louisa Cooper), у Вулвичу, у Кенту (Woolwich, Kent). Госпођа Стобарт је 1910. године основала Мобилне женске јединице за болесне и рањене (The Women's Sick and Wounded Convoy Corps) a 1914, била међу оснивачима Лиге женске националне службе (The Women's National Service League), за пружање помоћи у време рата, у земљи и иностранству. За велики допринос у медицинској и хуманитарној мисији, Србија је госпођу Мабел Стобарт одликовала Орденом Светог Саве III реда. Након повратка у домовину, госпођа Мабел Стобарт је путовала широм Британије, Канаде и Америке и у име СПФ промовисала Србију, а сакупљене прилоге слала Српском Црвеном крсту. По повратку у домовину, објавила је књигу Пламитећи мач у Србији и gруїge (Mabel Anne Saint Clair Stobart, The Flaming Sword in Serbia and Elsewhere (London: Hodder and Stoughton, 1916)), која је, као сведочанство о страдању српског народа у Првом светском рату, изазвала велику пажњу и имала непроценљиву улогу у промоцији српске културе и историје у Великој Британији и на другим континентима. 
Јењавањем епидемије, госпођа Стобарт је у лето 1915, формирала диспанзере у Крагујевцу, Наталинцима, Лапову, Витановцу, Овчар Бањи, Рековцу и на Руднику. Ови диспанзери намењени за лечење цивилног становништва, имали су подршку српског војног санитета, а њихово формирање помогли су локални учитељи и попови. Своју велику љубав за српски народ, показала је у спашавању српских рањеника и болесника у крагујевачкој болници, у организацији седам диспанзера широм Шумадије, у деловању тзв. Летеће јединице, која је пратила деловање српске дивизије, у заједничкој судбини великог егзодуса преко Албаније, у промоцији у послератном периоду. У обележавању Видовдана у Лондону, госпођа Стобарт има помоћ и подршку оца Персивал Перси Деармера (Rev. Percival Percy Dearmer, 1867-1936), свештеника. Персивал Деармер је боравио у Србији, у пратњи супруге дечијег писца Мабел Деармер (Mrs. Jessie Mabel Pritchard Dearmer, 1872-1915), болничарке, која је преминула у Крагујевцу, почетком јула 1915. године.

Прошло је сто година од времена када је госпођа Мабел Стобарт, сифражеткиња и хуманиста, Британка по рођењу, космополита по опредељењу, писала о српском народу:

„Српски народ, који сам срела у току првих шест месеци, много ми се допао. Они су љубитељи поезије и лепе уметности; паметни и маштовити; отворени за нове идеје; топлог срца, весели, с лепим смислом за хумор; храбри као војници, одважни као грађани; одговорни до најбољег могућег, док стреме идеалима ван могућег домашаја. Како су само могли да не пробуде одзив симпатија? Постоји ли неки други балкански народ, којем би се сигурније могла поверити одговорност за културну еволуцију на Балкану, осим нашем најмлађем савезнику? То сам снажно осетила у току њиховог тријумфа, али сам још снажније доживела у време њихове несреће. “36

${ }^{36}$ Popović Filipović, Iz postojbine javora, 153. 
["The Serbian people whom I had met during the first six months had appealed strongly to me. Lovers of poetry and of peaceful arts; intelligent and imaginative; impressionable to new ideas; warm-hearted, gay, with a keen sense of humour; brave as soldiers, courageous as citizens; responsive to the best within reach, whilst aiming at ideals possibly beyond reach: how could they fail to awaken a sympathetic response? Is there any other of the Balkan nations, which could more safely be entrusted with responsibility for the evolution of culture in the Near East, than our youngest ally? I had felt this strongly during their time of triumph, but I felt it more strongly in their time of trouble."]

Поред пет медицинских мисија у Србији, Шесте медицинске јединице СПФ на Крфу, Српски потпорни фонд наставља своју мисију преко болнице у Соровићу, на Солунском фронту, СПФ болнице у Бастији, на Корзици, хуманитарне и социјалне помоћи у Тунису и Мароку, радом болница и диспанзера у послератном периоду. Посебно важна делатност Српског потпорног фонда била је помоћ српских заробљеника у логорима у Аустроугарској, Немачкој и Бугарској, који се обављао посредством помоћног бироа, формираног у Швајцарској. Успостављена је веза с око 7о.ооо српских заробљеника и од маја 1916, достављани су им пакети с храном, ако не више оно бар једна векна хлеба недељно. ${ }^{37}$

Отац Николај Велимировић је сарађивао и подржао деловање Српског потпорног фонда у свим хуманитарним акцијама, посебно у школовању српских ученика и студената. У мисији човекољубља, отац Велимировић је упознао многе хуманисте, а за пријатеље имао Чедомиља Мијатовића, Димитрија Митриновића, Роберт Вилијем СитонВотсона, Хенри Викем Стида, сер Артур Џон Еванса, госпође Гертруде Карингтон Вајлд и многе друге. Није нам

37 УП. „Najveći dobrotvori Srbije u ratu - The Serbian Relief Fund“, Nova Evropa, knj. 12, br. 16 (Zagreb, 1. decembar 1925), 492-495. 
познато када је дошло до свих појединачних сусрета, али се зна да је деловање СПФ и Српског Црвеног крста повезало многе у заједничкој мисији доброчинства, за српски народ у Србији, у избеглиштву, наставио у послератном периоду.

\section{Отац Николај Велимировић у мисији школовања српских избеглих ученика, студената и теолога у Великој Британији}

У великом егзодусу српске војске и санитета, крајем 1915, повлачио се велики број избеглица, породица с малом децом, ученика, гимназијалаца и студената. Министарство просвете и црквених дела, које је по искрцавању обновило свој рад на Крфу, имао је примарни задатак да склони и заштити хиљаде српске избегле омладине. Један број српске школске омладине је прихватила Грчка (углавном у Сoлуну и Водени), преко шест хиљада српских избеглица је прихватила Корзика (највећи број породица с децом), преко 3.000 ученика и студената је примила Француска, док је Велика Британија примила око 450 ученика и студената. ${ }^{38}$

Пресудну улогу у школовању српске омладине у Великој Британији имали су представници Српског потпорног фонда, који су посредовали преко Париза и професора Јована Цвијића, па тако допринели да се и британске школе укључе. Тако су по доласку у Лондон, у пролеће 1916, српски избегли ученици и студенти били распоређени у школским и универзитетским центрима у градовима широм земље. Групу српске избегле омладине, питомаца Српског потпорног фонда, чинила су мала деца и младићи, од основношколског узраста, гимназијалаца, ученика стручних и трговачких школа, до универзитетских студената.

\footnotetext{
${ }^{38}$ Опширније: Душица Бојић, Срӣске избеїлице у Првом светиском райи: 1914-1921, Библиотека „Јазон“, књ. 17 (Београд: Завод за уџбенике, 2007).
} 
Српски ученици и студенти су били распоређени у следећим градовима: у Абердину (Aberdeen, 10), старешина Михајло Ђорђевић, у Бирмингему (Birmingham, 23), ${ }^{39}$ старешина Спасоје Прица, у Глазгову (Glasgow, 18), старешина Владимир М. Вукмировић, у Дандију (Dundee, 25), старешина Милорад Ванлић, у Единбургу (Edinburgh, 25), старешина Душан Марковић, у Кардифу (Cardiff, 9), гимназијалци и студенти, у Кембриџу (Cambridge, 47), старешина Милан Луковић, у Лидцу (Leeds, 18), Лазар Шуваковић, старешина прве групе у Лондону (London, 37), професор Милан Мајзнер и др Славко Шећеров, старешине друге групе у Лондону (London, 39), др. Драгутин Суботић, старешина у Редингу (Reading, 31), старешина Јован Алексић, у Манчестеру (Manchester, 5), у Мејденхеду (Maidenhead, 6) и у Чендлерсфорду (Chandlers Ford, 22), старешина Јован Спасић.

Британска организација народног братства (National Brotherhood Council) се прихватила оснивања једног српског сиротишта у Фавершаму (Faversham), у Кенту, које је примило око сто деце, узраста 7-14 година. Сиротиште је деловало уз финансијску помоћ СПФ, Америчког Црвеног крста, Британског Црвеног крста и Војног министарства Краљевине Србије. ${ }^{40}$

Свака група српске омладине на школовању у Великој Британији, у избеглиштву 1916-1919, за старатеља је имала једног учитеља или свештеника. Учитељи и наставници, који су пратили српску омладину на школо-

\footnotetext{
39 Захваљујући дами Елизабет Мери Кадбури (Dame Elisabeth Mary Cadbury, 1858-1951) и њеном супругу Џорџу Кадбурију (George Cadbury, 1839-1922), богатом произвођачу чоколаде и великом филантропу, закупљена је једна кућа у Бирмингему, где је смештено 23 српских ученика. Госпођа Кадбури, позната сифражеткиња, била је активна чланица СПФ, а с леди Абердин и Ани Христић учествовала је у раду Међународне асоцијације жена, која је међу чланицама имала Краљевину Србију.

40 Број српске избегле омладине је варирао током њиховог двогодишњег школовања; подаци су наведени према следећем истраживању: Јелица Рељић, „Школовање српске омладине у Великој Британији 1916-1919“, Balkanika XXIV (1993): 101-122.
} 
вању у Британији, у периоду 1916-1919, били су: Милан Мајзнер,41 гимназијски професор и преводилац, Милорад Ванлић, професор, др Драгутин Суботић, Милан Луковић и др Славко Шећеров. Групу су пратили преводиоци Милан Брадић и Александар Видаковић. Међу свештеним лицима, старатељи су били Душан Марковић (1874-1935), православни свештеник, који је пратио српске ученике у Единбургу и Војислав Јањић (1885-1946), српски богослов, старешина ђачке групе на школовању у Лондону. Поред редовног школског програма, српски ученици су имали веронауку, која је била у организацији српске цркве, под старешинством Панте Мајсторовића, свештеника, док су вероучитељи били Александар Илић и Никола Ђорђевић. Они су, по распореду, обављали своју дужност, па тако су најмлађима предавали хришћанску науку, вршили разне црквене обреде и чинодејствовали при православној служби.

У циљу организованог праћења школовања српских ученика и студената, формиран је Образовни комитет Српског потпорног фонда (The Educational Committee of the Serbian Relief Fund). Комитет за надзор и школовање

41 Милан Мајзнер (1868-1942), гимназијски професор, полиглота, преводилац и писац, био је старешина српских избеглих ученика у Лондону у време Првог светског рата. Рођен је 1868, у Београду, као син Јосифа Мајзнера (1828-1894), Чеха, и Александре Петровић, Српкиње. Јосиф Мајзнер, дугогодишњи главни библиотекар Народне библиотеке у Београду и Александра, професорица имали су четири сина: Милана, Венцеслава, Анастаса и Павла. Синови су стекли лепо образовање и постали угледни грађани у Србији. Милан Мајзнер је завршио Велику школу у Београду, а службовао је као гимназијски професор у Лесковцу, Нишу, Пожаревцу, Крагујевцу, Пироту, Смедеревској Паланци и Београду, у Другој и Четвртој гимназији. Као полиглота, који је говорио француски, енглески, латински, немачки и грчки, превео је неколико дела класичне филозофије и историје, сарађивао за часописе Просветини іласник, Коло, Срйски етиноірафски зборник, Годишнииа Николе Чуйића, а покренуо је и часопис La petite Revue, на француском језику (Славица Поповић Филиповић, Чеси у Србији, Лекари, апотекари, ветеринари, болничарке и њихови потомци (1835-1918), рукопис у припреми за штампу). 
српске школске деце и студената био је у саставу: председница госпођа Гертруда Карингтон Вајлд (Mrs. Gertrude Carrington Wild, 1856-1945), чланови др Роналд Бароуз (Dr. Ronald Montagu Burrows, 1867-1920), археолог и директор Краљевског колеџа у Лондону (King's College, London), др Томас Фостер (Dr. Thomas Gregory Foster, 1866-1931), лингвиста, проректор Универзитетског колеџа у Лондону (The University College, London), сер Хенри Гуч (Sir Henry Cubitt Gooch, 1871-1959), политичар, члан Парламента, одборник ширег подручја Лондона (London County Council), Xeнри Ноел Брејлсфорд (Henry Noel Brailsford, 1873-1958), новинар, дописник листова The Guardian и The Daily News, госпођа Кари (Mrs. Curry), госпођица Меквин (Miss McQueen), отац Николај Велимировић и историчар књижевности Павле Поповић,42 професор београдског универзитета и академик.

Почетком 1918. године, формиран је Просветни савет Српског потпорног фонда, који је деловао при канцеларији инспектора Министарства просвете у Лондону. Просветни савет је био у саставу: просветни инспектор, професор Павле Поповић, заменик, Михаило Поповић, заменик, ам-

42 Павле Поповић (1868-1939), професор српске књижевности на Филозофском факултету Београдског универзитета више од тридесет година (1904-1938), ректор Београдског универзитета (1924-1928), уредник Срйской книжевноі іласника, академик и врло угледна личност у српском друштву. Професор Поповић је имао велику улогу у периоду Првог светског рата. Као политичар, професор Поповић је у Лондону био члан Југословенског одбора и уредник билтена Press Ecstracts (1916-1917). У Енглеској је написао и објавио књигу Jуїословенска књижевности, чије се прво издање појавио у Кембриџу 1918. Поред заступљених биографија и прилога књижевника Срба, Хрвата и Словенаца, професор Поповић је уврстио оца Николаја Велимировића, као представника српског беседништва. Професор Поповић и отац Велимировић су, као културни изасланици српске владе у Британији у току Великог рата, а уз помоћ и подршку Српског посланства, поред промоције Србије, успоставили многе везе и сарадњу, које су се наставиле и у послератном периоду. Између осталог, они су били чланови Образовног комитета СПФ у Британији, па тако су у сарадњи с британским представницима организовали школовање српске избегле омладине у британским школама у поменутим градовима. 
басадор Јован М. Јовановић, историчар Тихомир Ђорђевић, књижевни критичар Богдан Поповић, дипломата и универзитетски професор Ђорђе Ђурић, отац Николај Велимировић и професор Јован Цвијић.

Бригу о здравственом стању српских ученика и студената, водило је Српско посланство у Лондону и Српски потпорни фонд, др Војислав Субботић, у време свог боравка у Лондону, а врло често су то чинили и британски добротвори. Међу бројним добротворима била је госпођица Хилда Лоример (Miss Elizabeth Hilda Lockhart Lorimer), предавач класичних наука на Сомервил колеџу у Оксфорду (Somerville College, Oxford), која је пружила велику подршку српским избеглица у Оксфорду.43

\section{Српски студенти теологије у Великој Британији}

Група српских избеглица, која је студирала теологију у Оксфорду, била је под старатељством оца Николаја Велимировића, ректора српске богословије у Британији. Касније ову дужност обавља Јосиф Цвијовић (1878-1957), који је по завршеној Богословији у Београду и Кијеву, једно време пре-

\footnotetext{
${ }^{43}$ Хилда Лоример (Miss Elizabeth Hilda Lockhart Lorimer, 1873-1954), ћерка Роберта Лоримера (Reverend Robert Lomrimer), шкотског свештеника је, по дипломирању на Кембриџу, изабрана за предавача класичних наука на Сомервил колеџу у Оксфорду (Somerville College, Oxford). У Првом светском рату, пријављује се за добровољну болничарку, па тако је у саставу Болнице шкотских жена, у Јединици Гиртон и Њунхам (The Girton and Newnham Unit), лечила српске рањенике и болеснике у Солуну. По повратку са Солунског фронта, Хилдин дом у Оксфорду је био отворен за српске избеглице, којима је пружила велику помоћ у туђем свету. После рата, Хилда Лоример је скоро сваке године обилазила Србију, објавила један број чланака о историјском и културолошком наслеђу српског народа, дала велики научни допринос у истраживањима културолошког наслеђа Југославије, у оквиру међународног пројекта (уп. Slavica Popović Filipović, Velike žene u Velikom ratu / The Great Women in the Great War, Biblioteka „Hrestomatija“ (Pančevo: Mali Nemo, 2020), 154).
} 
давао на београдској Богословији и руководио Монашком школом у манастиру Раковица, а у балканским и Првом светском рату, био војни свештеник. У периоду 1916-17, на Теолошки факултет у Оксфорду је примљено дванаест свршених српских богослова, а један богослов је уписан на Теолошки факултет у Кембриџу. Групу богослова у Оксфорду су чинили: Иринеј Ђорђевић,"4 Јустин Поповић, Јован Стојановић, Павле Јефтић, Јелисије Андрић, Милоје Милошевић, Светислав Никић, Драгић Пешић и други.

Међу православним свештеницима у Британији био је Јустин Поповић (1894-1979), рођен као Благоје у Врању 6. априла 1894. године. Благоје Поповић је на почетку Првог светског рата био мобилисан у ђачку чету, при Моравској сталној војној болници у Нишу, која је деловала под управом др Владимира Станојевића. У саставу Моравске војне болнице, Благоје учествује у повлачењу, па стигавши у Скадар, моли патријарха Димитрија за монашки постриг. Уз благослов патријарха Димитрија, Благоје постаје монах Јустин. После српске голготе преко Албаније и искрцавања на обалу, Јустин Поповић је са српским избеглицама пребачен у Британију.

Подстреком оца Николаја Велимировића, Јустин Поповић је уписао Теолошки факултет у Оксфорду, потом наставио студије теологије у Лондону (1916-1926). У Лондону је завршио докторат „Филозофија и религија Ф. М.

\footnotetext{
${ }^{44}$ Иринеј Ђорђевић (1894-1952), српски богослов и доктор теологије, рођен је у селу Врнчани код Горњег Милановца. По завршеној Богословији у Београду, послат је у Петроград, на почетку Првог светског рата. У Оксфорду је завршио богословске студије и стекао докторат из теологије. У току свог избеглиштва у Оксфорду био је секретар, а потом и председник српског бироа у Енглеској. По ослобођењу био је епископ далматински Српске Православне Цркве, са седиштем у Шибенику. У Другом светском рату интерниран је у италијанско заробљеништво, где је остао до краја рата. По ослобођењу, одлази у Америку. Године 1949, враћа се у Енглеску, где ће предавати на Кембриџском универзитету. Преминуо је у Кембриџу, а сахрањен је у Лондону. Његови земни остаци пренети су 1991. године у родно место Врнчани.
} 
Достојевског“, који није прихваћен, па тако је он докторирао касније у Атини. Јустин Поповић је заједно са својим колегама уређивао часопис Хришћански животи, читавих двадесет година. У послератном периоду, судбина је Јустина Поповића довела у Битољ, као професора Битољске богословије, док је Николај Велимировић постављен за епископа жичког и охридског.

У току 1917. године примљена је група 50 српских ђакабогослова, који су дошли из Русије, Грчке и Француске. Одбор, који се бринуо о њиховом школовању, укључио је виђене британске црквене поглаваре, политичаре и друге угледне личности. Председник Одбора је био Ендрју Карнеги (Andrew Carnegie, 1835-1919), богат шкотско-амерички индустријалац и познат филантроп. За управника Српског богословског течаја, постављен је Јосиф Цвијовић, суплент Богословије Св. Сава, а за наставнике су именовани свршени питомци Духовне академије: јеромонах др Николај Велимировић, суплент Богословије Св. Саве, јеромонах Дамаскин Грданички, јерођакон Демостен Илић, свештеник др Војислав Јањић и суплент и свештеник Милун Милутиновић.

У Лондону је формиран енглески Комитет за помоћ српских богослова, чији је председник био архиепископ Кентерберија, који је имао помоћ лорда Солзберија (Lord Salisbury), као извршног председника. Ђаци-богослови су били смештени у два колеџа: група од 12 млађих ђака била је у Дорчестеру (Dorchester, Dorset), а група од 25 старијих ђака је била у Кадесдону (Cuddesdon, South Oxfordshire). Настава је почела 26. марта 1918, а школски програм је био у организацији српских наставника, који су пратили упутства српског патријарха Димитрија, митрополита Србије и Милоша Трифуновића, Министра просвете и црквених послова. Један од предмета је био енглески језик, који су организовали британски професори. Српски ђаци и студенти су имали и допунска предавања, која су држали српски избегли професори. Међу 
истакнутим професорима и предавачима, који су одржали бројне курсеве и предавања у различитим енглеским институцијама, били су Павле Поповић, Богдан Поповић, Милан Ћурчин, јеромонах Николај Велимировић. Цела мисија школовања српских ученика и студената теологије добила је подршку великог броја британских историчара и књижевника. Поред одржаних курсева и предавања, они су дали и значајан допринос у публиковању великог боја превода о историји српског народа, српске епске поезије, а објављен је и Српски молитвеник. ${ }^{45}$

\section{Школа Џорџ Хериот (George Hariot School), у Единбургу}

Доброчинство у школовању избеглих српских дечака и младића поделила је и Школа Џорџ Хериот (George Hariot School), у Единбургу. Школа је у пролеће 1916. прихватила 25 дечака, старости од 12 до 17 година, који су након повлачења преко Француске, стигли у Енглеску. Поред одличног резултата у гимназији, њих седморо је положило пријемни испит на Факултету техничких наука Универзитета у Единбургу.

У Шкотској, у оквиру бројних хуманитарних акција за помоћ Србији, у Единбургу су одржани Дани заставе (Flag Day), два пута, 28. јула 1917. године и 20. јула 1918. године. Сви прикупљени приходи су били намењени за издржавање и школовање 25 српских ђака у единбуршкој Школи Џорџ Хериот. Највећи филантроп школе био је сер Едвард Парот (Sir Edward Parrott, 1863-1921), политичар, професор и члан Парламента, представник либерала из Единбурга. За доброчинство, указано српским ученицима и студентима у избеглиштву у току Великог рата, сер Едвард Парот је одликован Орденом Светог Саве.

45 Рељић, „Школовање српске омладине у Великој Британији“, 110-112. 
Делегација високих британских, шкотских и српских представника је у неколико наврата посетила Школу Џорџ Хериот у Единбургу, о чему су извештавале шкотске новине. Децембра 1916, The Scotsman је објавио да су у делегацији високих званичника, поред сер Едварда Перота (Sir Edward Parrot), др Волис Вилијамсона (Dr. Wallace Williamson), господина Кларка (Mr. J. B. Clark), директора школе, били отац Николај Велимировић, дипломата Јован Јовановић, историчар Тихомир Ђорђевић, професор Павле Поповић, господин Милош Трифуновић, српски Министар просвете, професор Богдан Поповић, ${ }^{46}$ професор Миодраг Ибровац и госпођа Гертруда Карингтон Вајлд из Лондона, као председница Образовног комитета Српског потпорног фонда (the Chairman of the Educational Committee of the Serbian Relief Fund). ${ }^{47}$

У периоду између 1916-1919, кроз Школу Џорџ Елиот прошло је 25 српских дечака, који су за старешину имали свештеника Душана Марковића. Били су то: Ђорђе Алексић, Петар Деретић, Данило Ђокић, Милан Ђурић, Димитрије Дулкановић, Станко Илић, Живко Илић, Живојин Ковачевић, Гаврило Лазовић, Милорад Малетић,

\footnotetext{
${ }^{46}$ Богдан Поповић (1864-1944), професор, књижевни критичар и есејиста, рођен је у Београду, где је завршио гимназију и Велику школу. По завршеним студијама на Филозофском факултету у Паризу, изабран је за професора Велике школе, која је прерасла у Београдски универзитет. Професор Поповић је предавао француски језик, упоредну књижевност, теорију књижевности, естетику и општу историју. Уочи Првог светског рата постао је редовни члан Српске краљевске академије, а међу његовим највећим доприносима је покретање часописа Срйски книжевни іласник, који ће уређивати годинама. У време Првог светског рата, борави у Лондону, где је уз подршку Српског посланства радио на промоцији српске борбе, учествовао у школовању српских ученика и студената у Великој Британији. У Лондону, с братом професором Павлом Поповићем и оцем Николајем Велимировићем, судбину избеглиштва је прихватио као изазов и победу. Поповићево најзначајније дело је Анйолоїија новије срйске тирике (Загреб, 1911; Београд, 1912).

47 "Serbian Minister in Edinburgh," The Scotsman, Edinburgh (1. December 1916), The Scotsman (14. September 1918).
} 
Светомир Милисављевић, Божидар Молеровић, Ђорђе Николић, Душан Обрадовић, Ђорђе Османбеговић, Петар Пантелић, Данило Павловић, Миодраг Павловић, Михаило Радовановић, Александар Савић, Константин Станковић, Миливоје Стефановић, Тома Томић, Миодраг Тутуновић и Никола Васић. ${ }^{48}$ Поред успеха у школи, остала је успомена на рагби утакмицу, када је мали српски тим играо против великог шкотског тима, са старијим и искусним играчима. Српски дечаци су, како им је речено, играли за отаџбину, па је уследила победа с резултатом 8:3. После победе првог српског рагби тима, сакупљени прилози су предати Шкотском Црвеном крсту.

Одласком српских ученика из Школе Џорџ Хериот (George Hariot School), постављена је табла у знак захвалности:

„Ова плоча бележи вечну захвалност двадесет шест српских дечака избеглица, који су у време Великог рата, били примљени бесплатно и великодушно са свим образовним привилегијама од стране ове старе и почаствоване Фондације.“

["This Tablet records the everlasting gratitude of the Twentysix Serbian Refugee Boys, who, during the Great War, were freely and generously admitted to all the educational privileges of this ancient and honourable Foundation."]

Ова табла праћена је речима из Светог Писма (Мт. 25, 40):

„Заиста вам кажем: кад учинисте једноме од ове моје најмање браће, мени учинисте.“

${ }^{48}$ Miloš Paunović, Milan Igrutinović, Dejan Zec, Filip Baljkas, Izbeglištvo u učionici: srpski studenti $i$ daci $u$ Velikoj Britaniji za vreme Prvog svetskog rata = Exile in the Classroom: Serbian Students and Pupils in Great Britain During the First World War (Beograd: Centar za sportsko nasleđe Jugoistočne Evrope, 2016), 201-206. 
У заједничкој мисији хуманиста, отац Николај Велимировић и госпођа Гертруда Карингтон Вајлд, предложили су план да се ослободе српска деца, која су била у логорима без својих родитеља у Аустрији, Мађарској и Бугарској. Фебруара 1918, Министарство иностраних послова, Међународни Црвени крст и Папа су замољени да интервенишу.49

Отац Николај Велимировић је подржао и будуће акције СПФ у заштити српске избегле деце, расуте по европским земљама, а посебно српску ратну сирочад. Тако су госпођа Гертруда Вајлд и госпођица Ани Христић (Miss Annie Christitch), ${ }^{50}$ као чланице СПФ држале серију предавања у корист страдале Србије, узеле учешће на међу-

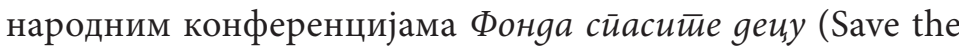
Children Fund), ангажовале се за оснивање Дома за ратну сирочад у Нишу.

49 Славица Поповић Филиповић, „Српски потпорни фонд и госпођа Гертруда Карингтон Вајлд“, Нишки весник, бр. 73 и 74 (април 2012) (доступно online: https://www.rastko.rs/rastko/delo/14418, Пројекат Растко, Историја медицине, 5.3. 2012. г.).

50 Госпођица Ани Христић (Miss Annie Christitch, 1885-1977), сифражеткиња, новинарка, полиглота, родила се у Београду, као унука Николе Христића, познатог српског политичара и вишегодишњег председника српске владе. Школовала се у Београду, Петрограду и Лондону. Као борац за женска права, заступала је Србију на конгресу Међународног савеза жена у Лондону (1912). Miss Annie Christitch, новинарка Дејли Ексйреса (Daily Express), била је међу првим женама ратним извештачима из иностранства. У балканским ратовима била је добровољна болничарка у резервној болници у Београду, заједно са сестром Џени и мајком Елизабет. У Првом светском рату долази у Србију као чланица Болнице шкотских жена, помаже збрињавање рањеника и болесника у Крагујевцу. С мајком Елизабет у Ваљеву формира Медицинску мисију Христић (The Christitch Mission), одбија да се повуче и међу последњим напушта окупиран град, новембра 1915. У послератном периоду у Великој Британији и Америци, ради на промоцији помоћи за Србију, сарађује с владиком Николајом Велимировићем и другим угледним личностима. Као сифражеткиња, велики борац за једнакост жена и полиглота, именована је за секретара Међународног савеза жена (The International Council of Women, 1924), па тако је блиска сарадница леди Абердин (Lady Aberdeen), вишегодишње председнице савеза (уп. Popović Filipović, Hrabrost između redova). 


\section{Сусрети оца Николаја Велимировића}

\section{се умножавају и трају}

У мноштву сусрета, раскршћа, даљих путоказа и путева издвајамо познанство оца Николаја Велимировића са Стивен Грејемом (Stephen Graham), ${ }^{51}$ познатим енглеским писцем. Стивен Грејем је забележио своје импресије о оцу Николају Велимировићу, приликом сусрета 1915. године:

„Он је говорио као да је тек стигао с поруком. Без похвала, без клишеа, без претходних размишљања, његове речи су учиниле да говори других свештеника са подијума изгледају бледо, као да су они говорили о вери, која је некада постојала." Истовремено, у истом тексту Грејем је на упечатљив начин додао: „Он (Велимировић) је био нежан, убедљив, оригиналан, као када читате Јеванђеље први пут. Духовност истине се ширила међу нама. “52

["He spoke arrestingly as if he had just arrived with the message. No compliments, no clichés, no wishful thinking, his

${ }^{51}$ Стивен Грејем (Stephen Graham, 1884-1975), рођен је у Единбургу, од оца Андресон Грејема (P. Andreson Graham), есејисте и уредника часописа Country Life. Као младић у Лондону, почео је да учи руски од Николаја Лебедева, што подстиче његово интересовање за Русију, које је трајало целог живота. Мада је једно време боравио у Америци, остаје привржен Русији, где је живео и радио као дописник Тајмса (The Times) и професор енглеског у Москви. Објавио је бројна дела, посвећена Русији: Changing Russia (1913), With the Russian Pilgrims to Jerusalem (1913), Russia and the World (1915), Russia in 1916 (1917), Peter the Great (1929), Boris Godunov (1933) и друга. У време Великог рата, у Лондону се дружи с Димитријем Митриновићем и Николајом Велимировићем, па отуда из прве руке шири своја сазнања о православљу. Роман Балкански манасӣир је, на известан начин, био симбиоза, која је повезала његове емоције према Босни, Србији и Русији.

52 Преузето из: Slobodan G. Markovich, "Activities of Father Nikolai Velimirovich in Great Britain during the Great War," Balcanica, Issue 48 (2017): 143-190: 166, https://doi.org/10.2298/BALC1748143M. 
words made the speeches of the other clerics from the platform seem dim, as if they told of a faith which once existed." A few paragraphs later, Graham added another vivid description: "He was gentle, persuasive, original, like a page of a Gospel read for the first time. The Spirit of Truth was pilgrimaging among us."]

Као што је већ познато у Великом рату у Великој Британији објављен је велики број научних историјских дела, превода српске историје и епске поезије, али и личних успомена и дневника о Србији и српском народу. Мада је највећи број публикација објављен у току рата, рат је наставио да инспирише многе и у послератном периоду. Тако се Стивен Грејем касније оглашава романима Bugoвgaн (St Vitus Day, London, 1930), који се бави сарајевским атентатом и Балкански манастиир (The Balkan Monastery, London, 1935), ${ }^{53}$ чија радња је била смештена у српском манастиру Свети Роман, близу Ражња. У Балканском манастиру, аутор прати судбину девојчице Десе, мале избеглице из Босне, која ратне године проводи у манастиру Св Роман с осталом децом, склоњеном од ратног вихора. Роман је највероватније настао као плод дружења Стивена Грејема с оцем Велимировићем, у време његовог боравка у Лондону. После ослобођења Грејем је посетио Југославију, што потврђују описи манастира Св Роман, Ражња, Ђуниса, Ниша, Топаонице, Прокупља, Куршумлије и Крушевца. У прилог нашој претпоставки је чињеница да је отац Велимировић био близак пријатељ нишког Епископа Доситеја,

\footnotetext{
53 Бранко Момчиловић, „Балкански манасиичр, Један енглески роман о окупацији 1915-1918“, у Крушевачки крај у окуйацији 1915-1918. іолине: зборник раяова са научноі̄ скуйа оgржаноі̄ у Крушевиу 12. и 13. јуна 1998. іоguне, Посебна издања / Историјски архив [и] Друштво за ослободилачке ратове Србије до 1918. године, ур. Миломир Стевић (Крушевац: Историјски архив - Друштво за ослободилачке ратове Србије до 1918. године, 2001), 93-99.
} 
који је дао благослов да се деца склоне у манастир, па тако био у центру овог подвижничког дела.

Како би се заштитила деца, чији су очеви били на фронту, Делфа Иванић, чланице Кола српских сестара и Женског савеза су 1912. године, покренуле идеју о оснивању Дечијег чувалишта у Београду. Покровитељство Дечијег чувалишта преузели су кнез Јован Константинович и кнегиња Јелена Петровна Романов, по којој ће дом добити име Чувалишӣе Светиа Јелена. Целу мисију је подржала и помогла госпођа Александра Павловна Хартвиг, Рускиња, добровољна болничарка и оснивач руских болница у Србији, у ослободилачким ратовима.

На почетку Првог светског рата, на иницијативу госпође Хартвиг, преко сто деце из Београда пребачено је у Ниш, што је остварено захваљујући нишком Епископу Доситеју (Драгутин Васић, 1877-1945) и његовим свештеницима. Чување и лечење ратних сирочића у Нишу преузели су српски лекари, нишки свештеници и особље руских болница све до великог егзодуса, крајем 1915. године. У време окупације, према запису нишког проте Жике Станковића, око сто деце је склоњено у манастир Свети Роман, далеко од пута и првог села. Старешина манастира, Михаило Поповић и отац Мојсије Бранкович су ову децу чували, хранили, одевали, васпитавали и лечили, једном речју сачували њихове животе од ратних страдања. Око 40 деце је остало да живи у манастиру све до ослобођења, када су послати у Београд на даље школовање.

У циљу веродостојности описа ратних догађања у Србији, Стивен Грејем, пријатељ оца Велимировића, а писац Балканскої манасӣира поткрепљује белешкама о српским фолклорним обичајима, уговарањем традиционалних бракова, венчања, крштења и побатримства, обављеним у српским црквама, у духу православне традиције. Можда би српски обичај побратимства, могао да добије ширу димензију и умножи се међу народима, тако би историја бележила више човекољубља, а мање ратова. 


\section{Отац Николај Велимировић је приближио}

\section{Православље Западу}

Отац Николај Велимировић је на својим стазама и путевима човекољубља, од Ћелија - малог српског манастира, до велике Лондонске катедрале, од Србије преко Ламанша и Атлантика, имао сусрете с краљевима и краљицама, лордовима и дамама, генералима и војницима, политичарима и писцима, професорима и учитељима, поданицима разних народа и различитих вера. Богатство својих сусрета, говора, казивања и богословско-књижевних дела бележио је на српском, енглеском, немачком, руском и француском језику.

Отац Николај Велимировић је био чест гост Одбора Српског потпорног фонда у Лондону, с којима је био повезан заједничком сарадњом, али и топлим пријатељством. Увек је био добродошао гост у Шкотској, посебно на Универзитету у Единбургу и Глазгову. Отац Николај Велимировић је био примљен од стране Комитета Болнице шкотских жена, новембра 1916. године. Приликом посете Единбурга, сусрео се с леди Каудри (Lady Annie Pearson Cowdray), великим филантропом и другим чланицама и захвалио се Шкотским женама на несебичној помоћи српском народу. Ратно пријатељство с леди Каудри, отац Велимировић наставља по ослобођењу у Београду, у Одбору за оснивање прве Школе за нудиље.

На позив Англиканске Цркве, Протестантске цркве, Цркве Енглеске, Шкотске цркве и других хришћанских цркава, отац Велимировић је држао говоре и проповеди широм Британије. Као познат говорник, користећи филозофију живота отац Никола Велимировић је желео да приближи и помири две цивилизације и културе, источну и западну. Отуда је отац Николај био често позиван да држи беседе у црквама, школама и универзитети- 
ма: у Вестминстеру (St. Margaret Church - Westminster), у Лондону (St. Paul Cathedral - London, the Church of St Mary-le-Bow - London), Оксфорду (Oxford), Jopку (York), Винчестеру (Winchester), Единбургу (Edinburgh), Бирмингему (Birmingham), Марлбороу (Marlborough) и другим местима. ${ }^{54}$

Као резултат академске активности у Великој Британији, према литератури, Николају Велимировићу је додељен Почасни докторат теологије на Кембриџском универзитету (Doctorate of Divinity - honoris causa - from the University of Cambridge) и Почасни докторат теологије на Универзитету у Глазгову, у Шкотској (Honorary Doctorate of Divinity from the Glasgov University, Scotland), а касније и Почасни докторат на Универзитету Колумбија, у Њујорку (The Columbia University, New York).

Међу бројним признањима, треба уврстити многа казивања других духовника о њему и његовим заслугама, које најбоље симболизују његову улогу у мисији, приближавања православља западу.

Ситон-Вотсон је у часопису Нова Евройа рекао:

„У току тужних ратних дана и избеглиштва, нико није више урадио да приближи овој земљи духовност Србије у духу Православне цркве, као што је то учинио отац Николај Велимировић.“

["During the dark days of war and exile no one did more to interpret to this country the soul of Serbia and the spirit of the Orthodox Church than Father Velimirovich."]

\footnotetext{
54 О активностима оца Николаја Велимировића у Великој Британији у току Великог рата, опширније у Markovich, "Activities of Father Nikolai Velimirovich in Great Britain during the Great War," 143-190.
} 
Архиепископ Велса, Рован Вилијамс (Rowan Williams, Archbishop of Wales), касније Архиепископ Кентеберија, записао је 2001. године:

„Епископ Николај Велимировић је за неколико генерација британских англиканаца био један у групи непогрешивих моралних и духовних дивова, који је донео неку дубину и изазов православног света на Запад.“”

["Bishop Nikolai Velimirovich was for several generations of British Anglicans, one of that group of unmistakable moral and spiritual giants, who brought something of the depth and challenge of the Orthodox world in the West." ${ }^{55}$ ]

Да се присетимо, Никола Велимировић, родом из села Лелића, се описменио у оближњем манастиру Ћелије. Многи сматрају да је манастир Ћелије био духовна престоница, јер је од 13. века имао улогу духовног путоказа у историји српског народа. Манастир Ћелије је кроз 800 година свога трајања, упркос историјским успонима и падовима, остао центар српске духовности, а како је изнедрио једног јеромонаха Николаја Велимировића доказује да није ни био мали српски манастир.

\section{Епилог}

У великом броју хуманиста широм света, страдања српског народа у Првом светском рату су подстакла најсветлије врлине човекољубља, па отуда враћамо сећања на ове незаборавне примере племенитости и после сто година. Многе светле примере хришћанске љубави и пожртвовања у мисији за српски народ у Првом светском рату, покренуо је

${ }^{55}$ Markovich, "Activities of Father Nikolai Velimirovich in Great Britain during the Great War," 184-186. 
отац Николај Велимировић, срцем, енергијом и харизмом мудраца, ватреном беседом и оштрим пером, у борби за слободу и спас мале, али храбре Србије. Можда отуда српска историја није само историја усахлих надања и узалудних страдања, већ и повест великих духовних светитеља, који су у временима прошлим у најтежим временима градили историју духовности српског народа.

$$
* *
$$

\section{Литература}

"Serbian Exhibition." Federal Magazine and the All-Red Mail, 77 (AprilMay 1916): 872.

"Serbian Minister in Edinburgh." The Scotsman, Edinburgh (1. December 1916).

"Serbian Minister in Edinburgh." The Scotsman, Edinburgh (14. September 1918).

"Servian National Hymn." The Sydney Morning Herald (25 November 1915): 10.

"Servian National Hymn." Translated by Elizabeth Christitch. The Horsham Times (Melbourne, 14 January. 1916): 3.

"Servian National Hymn." Translated by Elizabeth Christitch. The Horsham Times (Victoria, Australia) (14 January 1916): 3.

„Najveći dobrotvori Srbije u ratu — The Serbian Relief Fund“. Nova Evropa, knj. 12, br. 16 (Zagreb, 1. decembar 1925): 492-495.

Askew, Alice \& Claude. The Stricken Land: Serbia as We Saw It. London: Eveleigh Nash \& Co., 1916.

Balfour, Lady Frances. Dr Elsie Inglis. New York: Cosimo Classics, 2007. BBC. "Edinburgh, Scotland: The "Serbian Boys" of George Heriot's School." https://www.bbc.co.uk/programmes/po2fizng. 29 December 2014.

Berry, James F., May Dickinson Berry, W. Lyon Blease, et. al. The Story of a Red Cross Unit in Serbia. London: J. \& A. Churchill, 1916.

Blake, Jennifer. "Kossovo Day 28 June 1916." Britić - The British Serb Magazine (London, March 12, 2016). 
Chivers, Ellen Davies. A Farmer in Serbia. London: Methuen, 1916. Copeland, Fanny S. The Women of Serbia, with a preface by Lady (Ralph) Paget. London: The Faith Press for the Kossovo Day Committee, 1916.

Djokic, Dejan. "Whose Myth? Which Nation? The Serbian Kosovo Myth Revisited," in Uses and Abuses of the Middle Ages: 19th-21st Century, edited by Janos M. Bak, Jörg Jarnut, Pierre Monnet and Bernd Schneidmueller (Munich: Wilhelm Fink, 2009), 215-233; http://research.gold.ac.uk/id/eprint/3455, https://research.gold. ac.uk/id/eprint/3455/1/Kosovomyth2.pdf.

Fraser, Louise E. "Diary of a Dresser in the Serbian Unit of the Scottish Women's Hospitals." Blackwood Magazine, London (June 1915).

George Heriot's School. "Serbian Boys." www.george-heriots.com/ news/4438 serbian-boys.

Goldsvorti, Vesna. Izmišljanje Ruritanije: imperijalizam mašte. Preveli sa engleskog Vladimir Ignjatović i Srđan Simonović. Edicija „Geopoetika“. Beograd: Geopoetika, 2005.

Gordon, Cora and Jan. The Luck of Thriteen: Wonderings and Flight through Montenegro and Serbia. New York: E. P. Dutton and Company, 1916.

Graham, Stephen. Balkan Monastery. London: Ivor Nicholson and Watson, 1935.

Graham, Stephen. St Vitus Day. London: Ernest Benn, 1930.

Grba, Milan. "British Medical Units and Serbia in the First World War." South Slav Journal, Vol. 16, Nos. 3-4 (1995): 27-38.

Grogan, Lady [= Ellinor Flora Bosworth Smith]. Reginald Bosworth Smith: A Memoir. London: J. Nisbet \& Co., limited, 1909.

Grogan, Lady Ellinor Flora Bosworth Smith. The Life of J. D. Bourchier. London: Hurst \& Blackett, Limited, 1926.

Hutton, Isabel E. Memories of a Doctor in War and Peace. London Melbourne - Toronto: Heinemann, 1960.

Kossovo Day 1389-1916 [Prefatory Note and the ed. Nikolai Velimirovich]. London: Polsue, Limited, 1916.

Krippner, Monica. The Quality of Mercy: Women at War, Serbia 1915-18. London: David \& Charles, 1980.

Lawrence, Margot. Shadow of Swords - A Biography of Elsie Inglis. London: Michael Joseph, 1971. 
Lipton, Sir Thomas. The Terrible Truth about Serbia. London: British Red Cross Society, 1915.

Markovich, Slobodan G. "Activities of Father Nikolai Velimirovich in Great Britain during the Great War," Balcanica, Issue 48 (2017): 143190. https://doi.org/10.2298/BALC1748143M.

McLaren, Eva Shaw, ed. A History of the Scottish Women's Hospitals. London: Hodder and Stoughton, 1919.

McLaren, Eva Shaw. Elsie Inglish - the Woman with the Torch. London: Project Gutenberg, 2006.

Mijatovich, Chedo. Servia and Servians. London: I. Pitman and Sons, 1908.

Mijatovics, Elodie Lawton. The History of Modern Serbia. London: W. Tweedie, 1872.

Miller, Louise. A Fine Brother: The Life of Captain Flora Sandes. London: Alma Books, Ltd., 2012.

Miloyevitch, Milan G. Anglo-Yugoslav Cultural Relations. London, St. Clement's Press, 1944.

Mijatovich, Chedomille. The Memoirs of a Balkan Diplomatist. London: Cassell and Company, 1917.

Orthodoxy Cognate Page. "Vidovdan Address of Saint Nikolai Velimirovich and Saint Lazar the Great Martyr of Kossovo." OCP PanOrthodox Media Network, https://theorthodoxchurch.info/blog/ news/vidovdan-address-of-saint-nikolaj-velimirovic-and-saint-lazar-the-great-martyr-of-kosovo/, posted on July 1, 2019, seen on February 21, 2020.

Paget, Lady. With Our Serbian Allies. London: The Serbian Relief Fund, 1915.

Paunović, Miloš, Milan Igrutinović, Dejan Zec, Filip Baljkas. Izbeglištvo u učionici: srpski studenti i đaci $u$ Velikoj Britaniji za vreme Prvog svetskog rata = Exile in the Classroom: Serbian Students and Pupils in Great Britain During the First World War. Beograd: Centar za sportsko nasleđe Jugoistočne Evrope, 2016.

Petković, Nataša. Britanci o Srbiji 19oo. do 1920. Biblioteka „Dissertatio“ / Zadužbina Andrejević, 5. Beograd: Zadužbina Andrejević, 1996.

Popović, Bogdan, ur. Antologija novije srpske lirike. Zagreb: Matica hrvatska, 1911. 
Popović Filipović, Slavica. „Strašna istina o Srbiji, ser Tomas Lipton" ("The Terrible Truth about Serbia, by Sir Thomas Lipton"). Y Svedočanstva iz Prvog svetskog rata, 176-184. Valjevo: Istorijski arhiv, 2017.

Popović Filipović, Slavica. Dr Elsie Maude Inglis: The Serbian Mother from Scotland, 1917-2017. Valjevo: Istorijski arhiv, 2017.

Popović Filipović, Slavica. Hrabrost između redova: Ani Hristić u Srbiji i vreme odvažnih / Courage Between the Lines: Miss Annie Christitch in Serbia and the Time of the Brave. Beograd: Društvo istoričara Srbije - „Stojan Novakovic“", 2015.

Popović Filipović, Slavica. Iz postojbine javora: kanadsko-britanska medicinska i humanitarna pomoć Srbiji u Prvom svetskom ratu / From the Homeland of Maple Tree: the Canadian-British Medical and Humanitarian Help to Serbia in the First World War. Beograd: Srpsko lekarsko društvo, 2013.

Popović Filipović, Slavica. Svedočanstva iz Prvog svetskog rata / The Great War Revisited. Prevod Bob Filipović, Slavica Popović Filipović; [fotografije Bob Filipović]. Valjevo: Istorijski arhiv, 2017.

Popović Filipović, Slavica. Velike žene u Velikom ratu / The Great Women in the Great War. Biblioteka „Hrestomatija“. Pančevo: Mali Nemo, 2020.

Popović-Filipović, Slavica. Za hrabrost $i$ humanost, Bolnice škotskih žena u Srbiji i sa Srbima za vreme Prvog svetskog rata 1914-1918. Beograd: Signature, 2007.

Powell, Ann. Women in the War Zone. London: History Press, 2009.

Reiss, Archibald. Report upon the Atrocities committed by the AustroHungarian Army during the First Invasion in Serbia, English translation by Fanny S. Copeland. London: Simpkin, Marshall, Hamilton, Kent \& Co. Ltd, 1916.

Rutherford, Nichola. "Serbian boys' remembered in Edinburgh 100 years later." BBC Scotland, https://www.bbc.com/news/uk-scotland-edinburgh-east-fife-36427754. 4 June 2016.

Serbian Relief Fund: Report of the Mansion House Meeting, Berners Street, London, S. W., March 22nd, 1915. London, 1915.

Seton-Watson, R. V.“Orbituary Mme. Elizabeth Christitch.” The Times (London, February 2, 1933): 15. 
Seton-Watson, R.W. “The Spirit of the Serb." y Nataša Petković, Britanci o Srbiji 190o. do 1920., Biblioteka „Dissertatio“ / Zadužbina Andrejević, 5, 30-34. Beograd: Zadužbina Andrejević, 1996.

Seton-Watson, R.W. Serbia Yesterday, Today and Tomorrow. Westminster: Kossovo Day Committee, 1916.

Seton-Watson, R.W. The Balkans, Italy and the Adriatic. London: Nisbet \& Company Limited, 1915.

Seton-Watson, R.W. The Serbia's War of Liberation. London: Serbian Relief Fund, 1915.

Seton-Watson, R.W. The Spirit of the Serb. London: Nisbet \& Company Limited, 1915.

Smith, Angela K. British Women of the Eastern Front: War, Writing and Experience in Serbia and Russia, 1914-20. Manchester: Manchester University Press, 2016.

Staley, Mildred Ernestine Kaholamoana. "War Service with the Serbian Army, 1915-1917." In A Tapestry of Memories: An Autobiography. Honolulu, Hawaii Hilo Tribune-Herald, 1944.

Stebbing, Edward P. At the Serbian Front in Macedonia. London: John Lane Com., 1917.

Stobart, Mabel Anne Saint Clair. The Flaming Sword in Serbia and Elsewhere. London: Hodder and Stoughton, 1916.

Storr, Katherine. Excluded from the Record: Women, Refugees and Relief 1914-1929. Switzerland, Peter Lang AG, Internationaler Verlag der Wissenschaften, 2009.

[Velimirovich, Nicholai]. "Prefatory Note." In Kossovo Day, 1389-1916, 3-5. London: Polsue Limited, 1916.

Velimirovic, Nicholai. Serbia in Light and Darkness, With Preface by the Archbishop of Canterbury. With 25 Illustrations. London - New York: Longmans, Green and Co., 1916.

Velimirovic, Nicholai. The New Ideal in Education: An Address Given Before The League of the Empire on July 16 $6^{\text {th }}$, 1916. London: "The Electrician" Printing and Publishing Co., Limited, 1916.

Velimirovic, Nicholai. The Spiritual Rebirth of Europe. London: Faith Press, 1920.

Velimirović, Nicholas. Religion and Nationality in Serbia, With prefatory note by R. W. Seton-Watson. London: Nisbet \& Co. Ltd., 1915. 
Velimirović, Nicholas. The Soul of Serbia. Lectures Delivered Before the Universities of Cambridge and Birmingham. London: The Faith Press at the Faith House, 1916 [2 ${ }^{\text {nd }}$ edition: 1917].

Velimirovic, Nikolai. The Religious Spirit of the Slavs. Three Lectures Given in Lent, 1916. London: Macmillan, 1916.

Velimirovich, Nicholai. The Agony of The Church, With Foreword by the Rev. Alexander Whyte, D.D. London: Student Christian Movement, 1917.

Velimirovich, Nikolai. Christianity and War. Letters of a Serbian to his English Friend, Živa Crkva, Vol. III. New York, 1915 [2 $2^{\text {nd }}$ edition: London: The Faith Press, 1919].

Wilson, Francesca M. The Rebel Daughters of a Country House. London: Allen and Unwin, 1967.

Yovitchitch, Lena A. The Biography of a Serbian Diplomat. London: Epworth Press, 1939.

Бојић, Душица. Срйске избеіллице у Првом светиском райу: 19141921, Библиотека „Јазон“, књ. 17. Београд: Завод за уџбенике, 2007.

Габрић, Ненад П. Јован Јовановић Пижон и евройска gийломайија Србије (1913-1918), Библиотека „Јазон“, књ. зо. Београд: Завод за уџбенике, 2011.

Иванић, Делфа. Усйомене. Приредила Јасмина Милановић. Библиотека „Посебна издања“. Београд: Институт за савремену историју, 2012.

Марковић, Слободан Г. Гроф Чеgомиљ Мијайовић: Викйоријанаи међу Србима. Библиотека „Животописи“, књ. 1 (Београд: Досије - Правни факултет Универзитета у Београду, Центар за публикације, 2006.

Момчиловић, Бранко. „Балкански манастиир: Један енглески роман о окупацији 1915-1918“. У Крушевачки крај у окуйацији 1915-1918. іолине: зборник раяова са научноі̄ скуйа одржаноі̄ у Крушевиу 12. и 13. јуна 1998. іолине, Посебна издања / Историјски архив [и] Друштво за ослободилачке ратове Србије до 1918. године, ур. Миломир Стевић, 93-99. Крушевац: Историјски архив - Друштво за ослободилачке ратове Србије до 1918. године, 2001. 
Павловић, Коста Ст. Леgи Пецей, велика gобройворка срӣскоі нароga (1881-1958). Винзор, Канада: [Глас канадских Срба], 1958.

Петровић, Срећко. „Прилог познавању делатности Николаја Велимировића: Преписка са Робертом Гардинером“ (“А Contribution to the Study of Life and Work of Bishop Nicholai Velimirović: Correspondence with Robert H. Gardiner"). Теолошки йойлеgu / Theological Views, Година / Volume LII, Број/Issue 3 (2019): 677-710. https://doi.org/10.46825/tv/2019-3-677-710.

Поповић, Богдан, ур. Анйолойија новије срйске тирике. Београд: С. Б. Цвијановић, 1912.

Поповић Филиповић, Славица. „Мисија госпође Гертруде Карингтон Вајлд“. Свеске, бр. 134 [Панчево, Мали Немо] (2019): 191-20о.

Поповић Филиповић, Славица. „Српски потпорни фонд и госпођа Гертруда Карингтон Вајлд“, Нишки весник, бр. 73 и 74 (април 2012) (доступно online: https://www.rastko.rs/rastko/delo/14418, Пројекат Растко, Историја медицине, 5.3. 2012. г.).

Поповић Филиповић, Славица. „Српски потпорни фонд у Србији и са Србима у Првом светском рату и у послератном периоду“ ("The Serbian Relief Fund in Serbia and with the Serbs in World War One"). [Соколски зборник]: 800 іоgина срйске меgииине: [зборник раяова Трећеі научноі скуйа 8 оо їодина срйске меgицине], ур. Брана Димитријевић, 289-313. Београд: Infinitas - Српско лекарско друштво, 2012.

Поповић Филиповић, Славица. Свеgочанстива из Првоі светискоі̄ рат̄а. Ваљево: Историјски архив, 2017.

Поповић Филиповић, Славица. Чеси у Србији: Лекари, айотеккари, ветеринари, болничарке и юихови йотомми (1835-1918) [рукопис у припреми за штампу].

Поповић-Филиповић, Славица. „Елси Инглис (1864-1917) и Болнице шкотских жена у Србији у Великом рату. 1. део“. Срйски архив за целокуйно текарсииво, Volume 146, Issue 3-4 (March April 2018): 226-230. https://doi.org/10.2298/SARH170704167P.

Поповић-Филиповић, Славица. „Елси Инглис (1864-1917) и Болнице шкотских жена у Србији у Великом рату. 2. део“, Срйски архив за иелокуйно текарсииво, Volume 146, Issue 5-6 (Mау June 2018): 345-350. https://doi.org/10.2298/SARH170704168P. 
Поповић-Филиповић, Славица. „Срби на Корзици у Великом рату. 1. део" ("Serbs on Corsica in the Great War. Part 1"). Срйски архив за иелокуйно текарсииво, Vol. 146, Issue 7-8 (July August 2018): 470-476. https://doi.org/10.2298/SARH170704169P. Поповић-Филиповић, Славица. „Срби на Корзици у Великом рату. 2. део“ ("Serbs on Corsica in the Great War. Part 1"). Срйски архив за иелокуйно лекарсииво, Vol. 146, Issue 9-10 (SeptemberOctober 2018): 599-606. https://doi.org/10.2298/SARH170704170P.

Рељић, Јелица. „Школовање српске омладине у Великој Британији 1916-1919“. Balkanika XXIV (1993): 101-122.

Ристић, Љубодраг П. Србија у бритианској йолитиици 1889-1903. Посебна издања / Балканолошки институт САНУ, 124. Београд: Балканолошки институт Српске академије наука и уметности, 2014.

Сйоменица 1876-1936. Београд: Друштво Црвеног крста Краљевине Југославије, 1936.

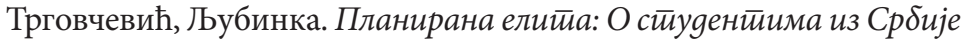
на евройским универзитетеиима у 19. веку. Посебна издања / [Историјски институт, Београд], књ. 43. Београд: Историјски институт - Службени гласник, 2003. 